\title{
Development and clinical translation of tubular constructs for tracheal tissue engineering: a review
}

\author{
Luis Soriano ${ }^{1,2,3,8}$, Tehreem Khalid ${ }^{1,2,4,8}$, Derek Whelan ${ }^{5}$, Niall O'Huallachain ${ }^{1}$, Karen C. Redmond ${ }^{6}$, \\ Fergal J. O'Brien ${ }^{2,3,4,7}$, Cian O'Leary ${ }^{1,2,3,4,7,9}$ and Sally-Ann Cryan'1,2,3,4,7,9
}

${ }^{1}$ School of Pharmacy and Biomolecular Sciences, RCSI University of Medicine and Health Sciences, Dublin, Ireland. ${ }^{2}$ Tissue Engineering Research Group, Dept of Anatomy and Regenerative Medicine, RCSI University of Medicine and Health Sciences, Dublin, Ireland. ${ }^{3}$ SFI Centre for Research in Medical Devices (CÚRAM), RCSI University of Medicine and Health Sciences, Dublin, Ireland. ${ }^{4}$ SFI Advanced Materials and Bioengineering Research (AMBER) Centre, RCSI University of Medicine and Health Sciences and Trinity College Dublin, Dublin, Ireland. ${ }^{5}$ Dept of Mechanical, Biomedical and Manufacturing Engineering, Munster Technological University, Cork, Ireland. ${ }^{6}$ National Cardio-thoracic Transplant Unit, Mater Misericordiae University Hospital and UCD School of Medicine, Dublin, Ireland. ${ }^{7}$ Trinity Centre for Biomedical Engineering, Trinity College Dublin, Dublin, Ireland. ${ }^{8}$ Joint first authors. ${ }^{9}$ Both authors contributed equally.

Corresponding author: Sally-Ann Cryan (scryan@rcsi.ie)

Shareable abstract (@ERSpublications)

A review focusing on the state of the art and clinical translation of tissue engineering and current approaches aimed at developing tubular substitutes for tracheal regeneration and restoration https://bit.ly/37kCB5z

Cite this article as: Soriano L, Khalid T, Whelan D, et al. Development and clinical translation of tubular constructs for tracheal tissue engineering: a review. Eur Respir Rev 2021; 30: 210154 [DOI: 10.1183/16000617.0154-2021].
Copyright $\odot$ The authors 2021

This version is distributed under the terms of the Creative Commons Attribution Non-Commercial Licence 4.0. For commercial reproduction rights and permissions contact permissions@ersnet.org

Received: 2 July 2021 Accepted: 26 July 2021

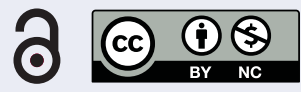

\section{Abstract}

Effective restoration of extensive tracheal damage arising from cancer, stenosis, infection or congenital abnormalities remains an unmet clinical need in respiratory medicine. The trachea is a $10-11 \mathrm{~cm}$ long fibrocartilaginous tube of the lower respiratory tract, with 16-20 tracheal cartilages anterolaterally and a dynamic trachealis muscle posteriorly. Tracheal resection is commonly offered to patients suffering from short-length tracheal defects, but replacement is required when the trauma exceeds $50 \%$ of total length of the trachea in adults and 30\% in children. Recently, tissue engineering (TE) has shown promise to fabricate biocompatible tissue-engineered tracheal implants for tracheal replacement and regeneration. However, its widespread use is hampered by inadequate re-epithelialisation, poor mechanical properties, insufficient revascularisation and unsatisfactory durability, leading to little success in the clinical use of tissue-engineered tracheal implants to date. Here, we describe in detail the historical attempts and the lessons learned for tracheal TE approaches by contextualising the clinical needs and essential requirements for a functional tracheal graft. TE manufacturing approaches explored to date and the clinical translation of both TE and non-TE strategies for tracheal regeneration are summarised to fully understand the big picture of tracheal TE and its impact on clinical treatment of extensive tracheal defects.

\section{Introduction}

Tracheal damage associated with narrowing, weakening or discontinuity of the airways is often a life-threatening condition. Defects in the conducting portion of the lower respiratory tract may arise from a wide variety of pathologies or clinical conditions. In particular, there is a significant unmet clinical need in terms of treatment options for long and extensive tracheal defects [1]. Currently, short-length tracheal damage is typically corrected by thoracic surgery including tracheal resection and end-to-end anastomosis, although this is not advised for those defects exceeding $2 \mathrm{~cm}$ in children and $5 \mathrm{~cm}$ in adults [2]. In such cases, patients are treated using slide tracheoplasty, tracheal reconstruction and novel artificial prostheses. Several complications, however, including granulation tissue formation and weakening of the implant over time, critically endanger their performance [1,3]. Therefore, there is an urgent need to develop novel solutions to promote the regeneration of native tracheal tissues [4].

In light of this unmet need and the evolving initiatives to potentially solve it, this review seeks to highlight the historical attempts at tracheal replacement and how the lessons learnt have impacted and directed 
current tissue engineering (TE) research attempts. First, we contextualise clinical needs with an overview of relevant epidemiology and physiological characteristics of the functioning trachea and thus the design requirements of a tracheal graft. Thereafter, an overview of current repair strategies is outlined, before summarising the significant experiences of clinical trials of various technologies.

\section{The clinical need for tracheal replacement and regeneration}

Tracheal damage or dysfunction in adults is commonly caused by traumatic injury, several types of cancer and benign conditions including tracheobronchomalacia (TBM) (table 1) [2, 5-16]. Although exact case numbers are unknown and challenging to estimate, tracheobronchial injuries are reported to represent 2.5$3.2 \%$ of trauma-associated deaths and $0.5-2 \%$ of admitted trauma patients with chest and neck injuries $[5,6]$. Malignant tumours affecting the airways can cause tracheal obstruction and collapse leading to the need for tracheal resection and reconstruction, including primary tracheal tumours such as squamous cell carcinoma and adenoid cystic carcinoma [9, 10]. Another pathology that can result in tracheal damage is TBM, an under-reported disease characterised by the weakening of airway walls due to softening of cartilage tissue covering the trachea and bronchi [11]. Finally, intensive care unit patients with prolonged intubation may develop laryngotracheal injuries due to endotracheal intubation procedures and tracheotomies. The incidence of post-intubation tracheal stenosis has been estimated as $6-21 \%$ of patients that underwent intubation [12, 13]. Moreover, recent studies suggest that around $10-15 \%$ of coronavirus disease 2019 patients require invasive mechanical ventilation and could develop tracheal stenosis once extubated [17].

In infants, congenital abnormalities present another unmet need for novel tracheal replacement solutions including tracheoesophageal fistulas, oesophageal atresia and birth abnormalities [14]. On the other hand, tracheal agenesis, a rarer abnormality, affects fewer than one in 50000 births [14-16]. Airway stenosis in infants and children is more challenging to treat than in adults, as resection and anastomosis are not feasible when the defect affects more than one third of the total tracheal length $(>2 \mathrm{~cm}[1])$. A range of stents have been used in attempts to support such patients, including Palmaz stents and biodegradable stents with limited success [18]. Although the reported incidence of pathologies affecting the trachea might seem low, factors such as death before reaching the hospital and common symptoms similar to other diseases (such as asthma) masks the true rate at which these conditions affect patients worldwide [19]. Furthermore, this misdiagnosis often leads to a high morbidity or mortality rate. Therefore there is a significant clinical need for tracheal regeneration [20].

Replacing the trachea: an overview of its characteristics and implant design requirements In order to develop new implants as tracheal substitutes that replicate physiological form and function, the complex biological and anatomical characteristics of the trachea must be understood, including cellular function, mechanical properties and vascularisation.

Although the tracheal structure appears to be a simple tube, in reality it is composed of challenging structural and compositional features to recapitulate. The trachea is the conducting portion of the respiratory tract, connecting the upper and lower respiratory tract, and is responsible for allowing air flow to and from the lungs, mucociliary clearance, and humidification of inspired air. It is composed of 18-22

TABLE 1 Epidemiology of tracheal defects

Pathology

Traumatic tracheobronchial injuries

Tracheal tumours

TBM

Post-intubation tracheal stenosis

Oesophageal atresia

Tracheal agenesis

Tracheo-oesophageal fistulas
Epidemiology

Reference

Cause of $2.5-3.2 \%$ of trauma-associated deaths

Present in $0.5-2.0 \%$ of trauma patients showing chest/neck injuries

$<1 \%$ of elective orotracheal intubations

$0.05-0.37 \%$ of endotracheal intubations

Tracheal malignancies present in $<1 \%$ of people

Primary tracheal carcinomas present in $<1 \%$ people each year

Overall epidemiology is unknown, but TBM is present in 23\% of COPD patients, $44 \%$ of patients

with chronic bronchitis and $1 \%$ of all patients undergoing bronchoscopy

$6-21 \%$ of patients that underwent intubation

$<1 \%$ of births

$<1 \%$ of births

$<1 \%$ of births

COPD: chronic obstructive pulmonary disease; TBM: tracheobronchomalacia. 
C-shaped hyaline cartilaginous rings that comprise around $80 \%$ of the tracheal circumference and are connected by the annular ligament longitudinally, and horizontally by the trachealis muscle [1]. The innermost layer of the tracheal wall at the interface with the lumen, the mucosal layer, is formed by the respiratory epithelium and the lamina propria. The ciliated pseudostratified columnar epithelium is responsible for mucociliary clearance, attraction of inflammatory cells during airway injury, secretion of a wide variety of mediators and represents the first barrier against pathogens and particles during breathing [21]. Therefore, any proposed construct must be airtight and hold the potential to regenerate pseudostratified respiratory epithelium to prevent bacterial infection [22].

The fibrocartilaginous layer of the tracheobronchial region is formed by C-shaped cartilaginous rings anchored by the trachealis muscle. Tracheal hyaline cartilage is highly cellularised and predominantly composed of collagen types II-VI and contains a high content of proteoglycans. Its main function is to maintain airway patency for sufficient airflow and to withstand forces exerted during respiration [23]. In tandem, the trachealis muscle is a smooth muscle tissue responsible for avoiding airway collapse by increasing the diameter of the trachea during respiration, coughing and asthma [1, 24]. Accordingly, a scaffold for tracheal replacement must demonstrate lateral rigidity and longitudinal flexibility to withstand inspiratory and expiratory forces, particularly at the midline posterior wall, where stent fractures occur with excessive coughing [3]. It should resist forces arising from coughing, neck movements and the pressure created by the adjacent oesophagus during feeding [1]. Mismatched properties will inevitably result in graft failure and airway collapse [25]. The precise mechanical forces acting on tracheal tissues are numerous and complex to determine, as abnormal situations including forced respiration, coughing and sneezing exert variable pressures on its physical properties. Additionally, tracheal cartilage is commonly studied as a biphasic material due to the collagen-rich solid matrix and the interstitial fluid [26], but has also been assumed to have both linear and non-linear elastic behaviours [27]. Whereas the trachealis muscle has been modelled as a hyperelastic material due mostly to its non-linear mechanical properties [28], and it is stiffer longitudinally than circumferentially $[1,29]$. Studies in this field are highly variable in terms of testing methods and specimen type used (table 2) [24, 27, 30-37], which causes significant challenges in understanding the mechanical properties of the native trachea in order to design potential replacement devices. However, the results from these studies can begin to form the foundation for the development of tracheal replacement constructs.

Vascularisation of the implant is a key factor that has hampered the success of tracheal grafts to date. It is a critical consideration to avoid tissue necrosis in the implant site and to support new cartilage and epithelium formation [38]. The trachea's blood supply is provided by the inferior thyroid artery forming a lateral anastomosis responsible for the formation of an intricate, wide network of small blood capillaries that provides blood supply to the respiratory epithelium and surrounding tissues [39]. This highly segmental blood supply of the trachea represents a challenge in replacement, as these small vessels do not lend themselves to easy and straightforward revascularisation. Tracheal revascularisation was a key factor in well-known failures in this field which involved the implantation of solid polymer tubes seeded with stem cells as a tracheal replacement. The cells were cultured on the scaffolds in bioreactors prior to implantation in patients but these procedures led to serious complications and death [40, 41]. This highlighted the importance of the trachea's blood supply and the need for any potential substitute graft to effectively support revascularisation to ensure graft performance and success.

TABLE 2 Mechanical properties of tracheal cartilage, trachealis muscle and whole trachea

\begin{tabular}{lcccc} 
& Specimen type & Test type & Modulus & Reference \\
\hline Tracheal cartilage & Human & Tensile & $16.92 \mathrm{MPa}$ & {$[27]$} \\
& Human & Tensile & $1-15 \mathrm{MPa}$ & {$[30]$} \\
& Porcine & Tensile & $5.62 \mathrm{MPa}$ & {$[31]$} \\
& & Compression & $1.36 \mathrm{MPa}$ & \\
Trachealis muscle & Ovine & Tensile & $10.6 \mathrm{MPa}$ & {$[32]$} \\
& Human & Tensile & $5.7-364 \mathrm{kPa}$ & {$[24]$} \\
Whole trachea & Human & Tensile & $0.84-34.15 \mathrm{kPa}$ & {$[33]$} \\
& Human & Tensile & $12-20 \mathrm{MPa}$ & {$[27]$} \\
& Human & Compression & $0.16-2 \mathrm{MPa}$ & {$[34]$} \\
& Porcine & Compression & $1.10 \mathrm{MPa}$ & {$[31]$} \\
& Ovine & Tensile & $1.5 \mathrm{MPa}$ & {$[35]$} \\
& Rabbit & Compression & $1.72 \mathrm{MPa}$ & {$[36]$} \\
& Rabbit & Three-point bending & $0.214 \mathrm{MPa}$ & {$[37]$} \\
\hline
\end{tabular}


In summary, due to the high complexity of the tracheobronchial region, any tubular approach aimed at regenerating tracheal tissue must be able to offer a suitable $3 \mathrm{D}$ environment for the formation of a respiratory epithelium and hyaline cartilage while allowing the development of a vascularised plexus to avoid necrotic tissue formation. Moreover, it should allow the infiltration of immune cells from the host immune system to avoid infection by inhaled pathogens during the regeneration of the respiratory epithelium. This significant challenge has seen the use of a wide range of strategies; the most historically significant and currently promising will be discussed at length in this review.

\section{Tracheal replacement strategies}

The first recorded attempts in tracheal resection and regeneration date back to the last decade of the nineteenth century [42-44]. After these early ground-breaking approaches, primary anastomosis was first performed in humans in 1886 [45]. Other approaches including the use of autogenous skin [46], fascial [47] and costal cartilage [48] grafts were later investigated, coupled with the first use of solid materials in prostheses [49]. The development of tubular tracheal substitutes has been further investigated using a wide variety of approaches including the use of transplanted bioprostheses [50], cadaveric tissue flaps [51], intestinal-derived tubes [52] and aortic homografts [53]. The success and shortcomings of these tracheal replacement strategies in clinical trials will be discussed at length below; however, attempts to replace long segmental tracheal defects have had limited success in long-term studies and current treatment options face substantial limitations. As a result, in recent years, research has shifted towards investigating TE approaches as a potential option to address this unmet medical need.

\section{TE approaches}

TE is primarily based on the use of a biomaterial scaffold, cells that are able to grow on the scaffold to form the replacement tissue and growth factors [54]. TE has shown promise in providing a solution for the regeneration of a range of other tissue types [55] and, as a result, TE in respiratory medicine has become more widely explored including tracheal tissue replacement. Different TE techniques have resulted in encouraging attempts at developing promising tracheal substitutes; however, a construct able to address vascularisation, mechanical stability and re-epithelialisation has not been developed to date [56-58]. Nonetheless, techniques investigated thus far have shown promise and may provide the basis for the future TE gold standard tracheal construct (figure 1). A selection of the most promising TE approaches is outlined below.

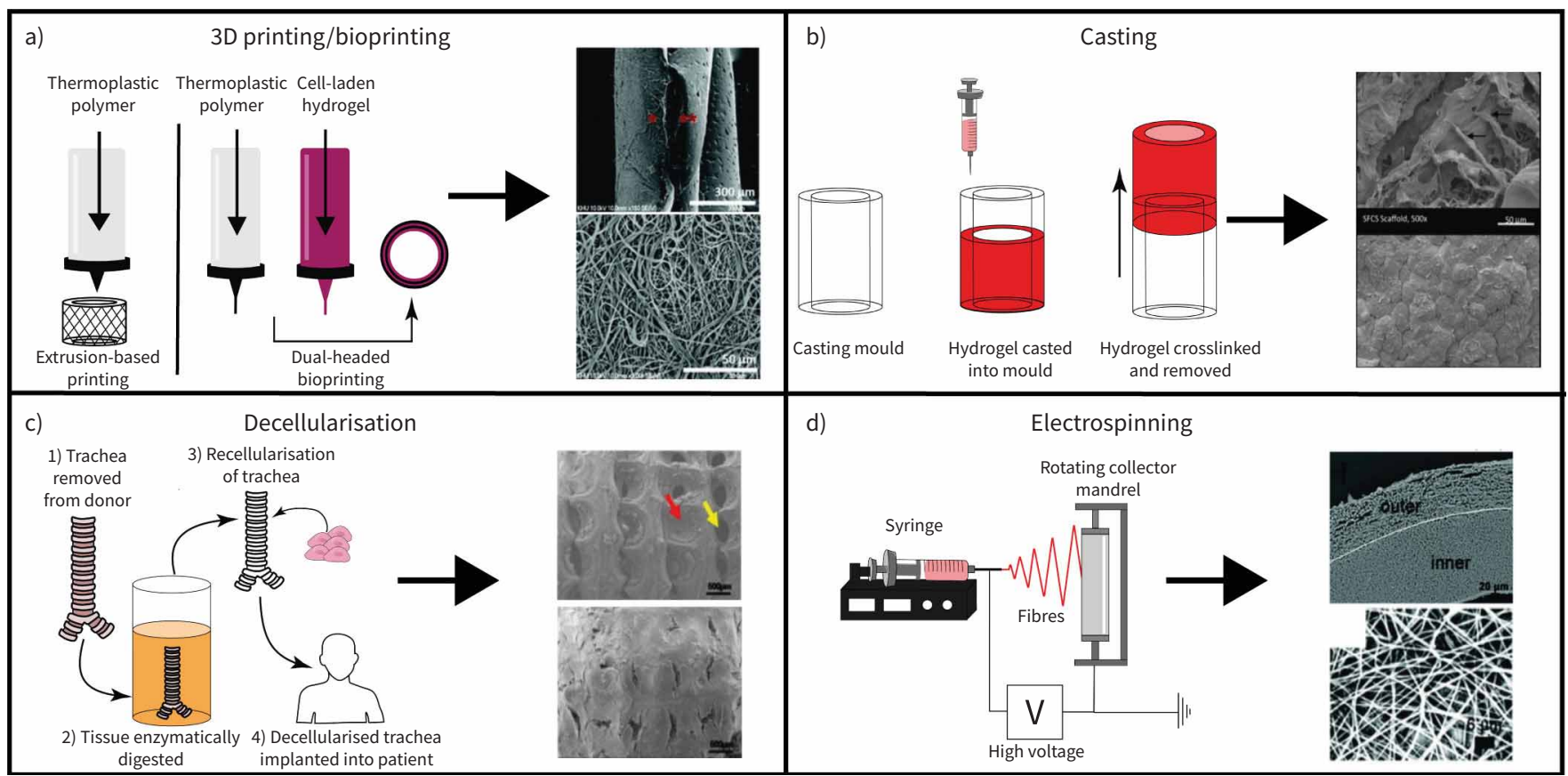

FIGURE 1 Different replacement strategies investigated for tracheal replacement: a) 3D printing/bioprinting, b) casting, c) decellularisation and d) electrospinning. Images adapted from $[59,60,70,86]$ with permission. 
Decellularised trachea

Decellularised tracheas (DTs) have been widely explored as a TE approach for tracheal replacement due to the advantages allografts provide including the correct airtight structure and the ideal extracellular matrix (ECM) for cellular attachment and growth. Tracheal decellularisation is accomplished by subjecting harvested donor trachea tissue to repeated cycles of various detergents and enzymes over a long period of time to remove genetic material and avoid immune reactions [36, 61]. Promising results from a small number of animal studies have observed revascularisation and re-epithelialisation in certain areas of grafts, although the majority of attempts have failed as a result of graft collapse or stenosis due to an immune response [62]. Complete removal of genetic material and cellular debris is not possible with existing techniques, which is likely to trigger an adverse host response in vivo. Complete removal would result in significant damage to the tracheal tissue, compromising its integrity as a matrix for cell growth and further weakening its mechanical properties [57]. While DT approaches show promise by providing an established architecture for cellular growth, they are severely limited by long expensive processing methods and donor-recipient matching limitations [36, 63]. However, the natural architecture of DT provides an excellent base for tissue growth over synthetic materials for mechanical integrity and could be combined with other TE techniques with promising initial results [64, 65].

\section{Electrospinning}

Electrospinning is a versatile technique that can be used with both synthetic and natural polymers to rapidly fabricate customisable multi-layered 3D constructs using a high voltage to eject the polymer of choice onto a collector plate forming nanofibrous structures [66-68]. Electrospinning has become widely used in respiratory TE applications due to its ability to produce fibrous scaffolds with a similar size-scale to native respiratory ECM using polycaprolactone (PCL), polylactic acid, polyethylene terephthalate and polyurethane (PU) [25, 66, 69-71]. Successful animal trials of different electrospun tracheal substitute materials are outlined in table 3 [72-85], although data from a number of studies have observed a more biocompatible response in cell-loaded electrospun scaffolds than in cell-free constructs [25, 69, 70]. Moreover, assessments of different material strength with this technique has typically ranged from matching the human trachea to being mechanically superior $[66,68]$. Electrospinning shows promise as a potential TE technique for tracheal replacement, but long-term animal studies have been limited.

\section{Casting}

Casting of materials has been widely used in a large range of TE applications allowing better control of scaffold geometries in 3D structures and reducing variability [35]. Casting methods in TE applications usually utilise distinctive blends of hydrogels that are highly customisable and able to provide a range of biochemical compositions, architecture and mechanical properties [86]. Hydrogels have been shown to facilitate cellular infiltration and vascularisation and have been used successfully in applications such as abdominal wall reconstruction [87], skin wound healing [88] and bone regeneration [89]. Patterned 2-hydroxyethyl methacrylate hydrogels were found to closely match the mechanical properties of neonatal ovine tracheas [39], while fibrin and agarose type I collagen hydrogels were proven to support growth of cultured ciliated epithelial cells and vascular networks [56]. The use of hydrogels as tracheal substitutes remains limited, but initial investigations on the basis of the requirements for tracheal substitutes have been promising although further research is needed to assure mechanical integrity and feasibility of hydrogel-based tubular constructs.

\section{0 printing}

In recent years, 3D printing (3DP) has been utilised for research purposes in the medical field as it allows for rapid fabrication of custom scaffolds for tissue replacement that can be tuned to alter properties including architecture, mechanical properties and rate of degradation [90, 91]. 3DP also facilitates the generation of complex multi-layered designs that can be personalised to meet a specific patient's trachea features [91]. The most commonly explored material in 3DP TE applications has been PCL due to its excellent mechanical properties, long-term stability and slow in vivo degradation rate. Recently, 3DP external tracheal stents made from PCL were granted United States Food and Drug Administration (FDA) approval for emergency use in paediatric surgery to correct TBM successfully [92]. Thus, the use of 3DP PCL in tracheal replacement research efforts has been widespread with studies fabricating tracheal scaffolds that display excellent resistance to compressive stresses and support cartilage tissue formation [2, 93]. However, PCL scaffolds have had very little success in animal studies due to an inflammatory response resulting in the formation of granulation tissue and stenosis [2, 94]. The use of novel materials in 3DP have been investigated, such as water-based biodegradable PU, which displayed adequate mechanical properties and supported the growth of cartilage tissue [95]. Attempts at 3DP of tracheal scaffolds with various materials to create unique tubular designs are still ongoing and have shown promising initial results but 
TABLE 3 Outcomes of pre-clinical animal studies of tissue engineering tracheal replacement attempts

\begin{tabular}{|c|c|c|c|c|c|}
\hline $\begin{array}{l}\text { Species, } \\
\text { sample } \\
\text { size }\end{array}$ & Material & Cells & Experiment details & Outcomes & Ref. \\
\hline Dog, $n=3$ & $\begin{array}{l}\text { PP mesh with radiated minced } \\
\text { dermal layer }\end{array}$ & Keratinocytes & $\begin{array}{l}\text { Keratinocytes were cultured on a patch of the } \\
\text { composite prosthesis which was then implanted } \\
\text { subcutaneously for } 1 \text { week, then implanted into a } \\
2 \times 3 \mathrm{~cm} \text { section within the trachea. }\end{array}$ & $\begin{array}{l}\text { Tracheas remained in animals for duration of study } \\
\text { ( } 5 \text { months) with some reports of stenosis and } \\
\text { initially some inflammation which resolved over } \\
\text { time. }\end{array}$ & [72] \\
\hline Dog, $n=10$ & $\begin{array}{l}\text { Porous copolymer of PLGA } \\
\text { scaffold, mounted on a prosthesis } \\
\text { framework, made of PP mesh } \\
\text { reinforced with PP rings }\end{array}$ & Keratinocytes & $\begin{array}{l}\text { Implanted in the peritoneal cavity for } 1 \text { week; wrapped } \\
\text { in greater omentum to vascularise prosthesis. } \\
\text { Complete surgical resection and replacement of a } \\
\text { thoracic tracheal segment }(5 \mathrm{~cm}) \text { was then } \\
\text { performed using the prosthesis. }\end{array}$ & $\begin{array}{l}\text { Still viable at } 2 \text { months, no signs of stenosis (one dog } \\
\text { omitted due to graft infection in peritoneum). }\end{array}$ & [65] \\
\hline Dog, $n=18$ & $\begin{array}{l}\text { PP mesh tube reinforced with a } \\
\text { PP spiral and coated with } 1 \% \\
\text { collagen solution which was then } \\
\text { freeze dried }\end{array}$ & $\begin{array}{l}\text { Autologous PB vs BM } \\
\text { aspirate vs BM MSCs }\end{array}$ & $\begin{array}{l}\text { Scaffolds were soaked in either aspirate or cell } \\
\text { suspensions. Prosthetic placed within } 5 \mathrm{~cm} \text { tracheal } \\
\text { defect. Animals were followed up to } 12 \text { months. }\end{array}$ & $\begin{array}{l}\text { Stenosis occurred in three dogs from PB group. Nine } \\
\text { of the } 12 \text { dogs in the BM aspirate and MSC groups } \\
\text { had an epithelial lining cover age of more than } \\
50 \% \text {. }\end{array}$ & [73] \\
\hline Dog, $n=5$ & $\begin{array}{l}\text { Nitinol frame coated in } 3 \% \\
\text { freeze-dried collagen }\end{array}$ & NA & $\begin{array}{l}\text { Placed in omentum prior to implantation for } 3 \text { weeks. } \\
2 \mathrm{~cm} \text { trachea section was removed and tracheal } \\
\text { prosthesis was sutured in with a } 5 \mathrm{~mm} \text { overlap. }\end{array}$ & $\begin{array}{l}\text { Assessed up to } 24 \text { months, four out of five dogs } \\
\text { survived post operatively. Airway stenosis was not } \\
\text { present. Epithelialisation was present; however, } \\
\text { vascularisation of graft was limited. }\end{array}$ & {$[74]$} \\
\hline Goat, $n=10$ & 3D-printed $\mathrm{PCL}$ & $\begin{array}{l}\text { Autologous articular } \\
\text { chondrocytes }\end{array}$ & $\begin{array}{l}\text { Scaffolds were seeded with } 1.2 \times 10^{8} \text { chondrocytes in } \\
\text { type I collagen gel and cultured for } 1 \text { week. } 3.5 \mathrm{~cm} \\
\text { section of trachea was removed and either grafted } \\
\text { back as control or scaffold was implanted. }\end{array}$ & $\begin{array}{l}\text { Initial granulation and stenosis were observed. Mean } \\
\text { survival was } 60 \text { days, which was significantly longer } \\
\text { than controls that quickly necrotised. }\end{array}$ & [75] \\
\hline $\begin{array}{r}\text { Mouse, } \\
\mathrm{n}=10\end{array}$ & Non-woven PGA mesh & Bovine chondrocytes & $\begin{array}{l}\text { The cell-seeded mesh was wrapped around a silastic } \\
\text { stent which was then implanted into nude mice for } \\
4 \text { weeks to generate cartilage prior to implantation } \\
\text { in cervical defect. }\end{array}$ & $\begin{array}{l}\text { Bovine chondrocytes generated cartilage. However, } \\
\text { only one animal survived the procedure, lasting for } \\
1 \text { week. Lack of vascularisation was cited as a } \\
\text { problem. }\end{array}$ & [76] \\
\hline $\begin{array}{l}\text { Porcine, } \\
\mathrm{n}=5\end{array}$ & Decellularised tracheal matrix & $\begin{array}{l}\text { Autologus MSC derived } \\
\text { chondrocytes and } \\
\text { epithelial cells }\end{array}$ & $\begin{array}{l}\text { Decellularised trachea was seeded with either cell type } \\
\text { or both cell types and implanted into a } 6 \mathrm{~cm} \text { defect. }\end{array}$ & $\begin{array}{l}\text { Animals were followed up to } 60 \text { days. Only the group } \\
\text { that received both cell types survived to day } 60 \text {. } \\
\text { Other groups suffered from infection or developed } \\
\text { stenosis. }\end{array}$ & {$[77]$} \\
\hline $\begin{array}{c}\text { Rabbit, } \\
n=6\end{array}$ & Freeze-dried PCL collagen sponge & Chondrocytes & $\begin{array}{l}\text { Scaffold was cultured within an in vitro bioreactor for } \\
8 \text { weeks to develop collagen content and expand } \\
\text { chondrocytes, prior to implantation in a } 1 \mathrm{~cm} \\
\text { defect. }\end{array}$ & $\begin{array}{l}\text { Mean survival of } 52 \text { days. At } 28 \text { days showed evidence } \\
\text { of granulation tissue covering graft, leading to } \\
\text { eventual stenosis. }\end{array}$ & [78] \\
\hline $\begin{array}{r}\text { Rabbit, } \\
\mathrm{n}=10\end{array}$ & PP mesh & Epithelial graft & $\begin{array}{l}\text { Hairless epithelial graft taken from the ear combined } \\
\text { with PP mesh and lateral thoracic fascia tubed } \\
\text { around a silicone catheter was implanted into } 2 \mathrm{~cm} \\
\text { defect. }\end{array}$ & $\begin{array}{l}\text { Followed up to max } 4 \text { weeks. } 70 \% \text { survival at week } \\
\text { 4. Epithelial grafts survived in all animals and had } \\
\text { fibro vascular connections to fascia. }\end{array}$ & [79] \\
\hline Rat, $n=5$ & Collagen sponge with PP mesh & $\begin{array}{l}\text { Gingival fibroblasts and } \\
\text { ASC }\end{array}$ & $\begin{array}{l}\text { Cells were seeded onto collagen sponge in collagen } \\
\text { solution, which was allowed to gel forming stratified } \\
\text { graft. A tracheal defect of } 3 \times 6 \mathrm{~mm} \text { was induced and } \\
\text { graft implanted. }\end{array}$ & $\begin{array}{l}\text { Pseudostratified ciliated epithelium containing goblet } \\
\text { cells was generated at day } 14 \text {. Combination of both } \\
\text { cell types gave best results. }\end{array}$ & [73] \\
\hline
\end{tabular}




\section{TABLE 3 Continued}

\begin{tabular}{l}
$\begin{array}{c}\text { Species, } \\
\text { sample } \\
\text { size }\end{array}$ \\
\hline
\end{tabular}

Rat, $n=3$

Scaffold-free reinforced with medical-grade PC

rings

Rabbit,
$\mathrm{n}=20$$\quad$ 3D-printed PCL $\quad$ Chondrocytes

Rabbit,

$\mathrm{n}=4$

3D-printed PCL

NA

hMSCS

Autologous BM-MNC

ondrocytes

(2)

chondrocyte suspension for 2 weeks and 2) scaffolds cultured in chondrocyte suspension for 4 weeks. Implanted into a $1.6 \mathrm{~cm}$ defect.

Four-axis FDM 3D-printed scaffolds were investigated for tracheal replacement over conventional 3D-printing techniques for more dimensionally accurate scaffolds. Implanted into $1 \mathrm{~cm}$ defects.

Porcine, 3D-printed PCL and decellularised

$\mathrm{n}=7 \quad$ bovine dermal collagen matrix

\begin{tabular}{|c|c|c|c|}
\hline $\begin{array}{r}\text { Rabbit, } \\
\mathrm{n}=12\end{array}$ & $\begin{array}{l}\text { 3D-bioprinted scaffold of PCL and } \\
\text { sodium alginate hydrogel }\end{array}$ & $\begin{array}{l}\text { Bone marrow-derived } \\
\text { MSCs and rabbit } \\
\text { epithelial cells }\end{array}$ & $\begin{array}{l}\text { Multi-layered scaffold of PCL and sodium alginate } \\
\text { hydrogel. Two layers of PCL used for providing } \\
\text { structural support and three layers of hydrogel } \\
\text { contained } 1 \times 10^{7} \text { cells } / 10 \mathrm{~mL} \text { of either MSC or } \\
\text { epithelial cells. Implanted into a } 1 \mathrm{~cm} \text { defect. } \\
\text { 12-week study. }\end{array}$ \\
\hline $\begin{array}{l}\text { Rabbit, } \\
\qquad \mathrm{n}=7\end{array}$ & $\begin{array}{l}\text { 3D-printed PCL and alginate/ } \\
\text { collagen type } 1 \text { hydrogel laden } \\
\text { with chondrocytes }\end{array}$ & Chondrocytes & $\begin{array}{l}\text { Dual-headed 3D printer used to form scaffold of PCL } \\
\text { and alginate/collagen type } 1 \text { hydrogel containing } \\
\text { chondrocytes. } 2 \mathrm{~cm} \text { defect. } 3 \text { - or 6-week study. }\end{array}$ \\
\hline $\begin{array}{r}\text { Rabbit, } \\
\mathrm{n}=16\end{array}$ & 3D-printed PLLA & Chondrocytes & $\begin{array}{l}\text { 3D-printed scaffolds were soaked in chondrocyte/ } \\
\text { hydrogel mixture and cultured for } 3 \text { days. Scaffolds } \\
\text { were pre-vascularised for two weeks prior to } \\
\text { implantation. Two in vivo groups were investigated: } \\
\text { no pre-vascularisation and } 2 \text { weeks of } \\
\text { pre-vascularisation. }\end{array}$ \\
\hline
\end{tabular}

3D-printed tracheal rings were sutured to a decellularised collagen matrix to obtain composite grafts to allow for better integration with surrounding tissue and provide a structural base for cellular infiltration and growth. Implanted into $4 \mathrm{~cm}$ defect.

pre-vascularisation.
Followed up on day 7 and day 35. Vascularisation and [80] epithelialisation were found to have increased; no cartilage formation was observed.

$60 \%$ of sheep survived up to 4 months. Graft stenosis present in all, encapsulation and infection occurred, no re-epithelialisation but granulation was observed.

Sufficient mechanical properties - no collapse. Higher survival rate in group 2 than 1 , but all animals died within 10 weeks. Most common cause of death in both groups was granulation tissue $(75 \%, 15 / 20$ animals). No re-epithelialisation occurred.

All animals survived until designated time points of 4 and 8 weeks. No signs of severe narrowing were observed. Four-axis scaffolds demonstrated less inflammation and better mucosal regeneration than conventional scaffolds, with ciliated epithelium observed on the lumen.

Five out of seven survived until the 3-month end point. Causes of death were cited as pneumonia and airway stenosis due to granulation tissue and secretions. At 3 months, grafts appeared vascularised with ciliated epithelium; however, granulation tissue was present in all remaining animals.

All animals exhibited no distress or graft failure until sacrifice at 12 weeks. Ciliated epithelial mucosa was observed fully covering scaffolds in all groups. Neo-vascularisation was abundant in all groups.

One animal died during surgical procedure due to an airway blood clot. Remaining animals suffered from respiratory distress. Examination showed large rate of stenosis at $83.4 \%$.

Control group suffered from serious morbidities and died on average $17+/-7$ days post-op, whereas in experimental group six out of eight animals survived until the end point, 2 months. Tracheal stenosis was mainly observed in the control group. 
TABLE 3 Continued

sample

Material

Cells

Experiment details

Outcomes

size

Rat, $\mathrm{n}=27 \quad$ Collagen/P(LA-CL) fib electrospun scaffold

RTEC and rat RTC

Bilayered scaffold fabricated using electrospinning. Contained dense fibres on the inner layer and porous yarns on the outer layer. Three groups investigated: PV, CS and bare scaffold. For cell seeding, RTECs were injected into inner lumen three times and then seeded with RTC on the outside surface also three times. Cultured for 7 days.

\begin{tabular}{|c|c|}
\hline $\begin{array}{l}\text { Porcine, } \\
n=6\end{array}$ & Decellularised trachea \\
\hline $\begin{array}{r}\text { Rabbit, } \\
\mathrm{n}=20\end{array}$ & $\begin{array}{l}\text { Composite graft of indirect } \\
\text { 3D-printed PCL and tmdECM }\end{array}$ \\
\hline
\end{tabular}

Decellularisation was performed using the HHP technique. Implanted into $1.5 \mathrm{~cm}$ defect. hydrogel/hTMSC sheets

$1 \mathrm{~cm}$ defect. Indirect 3D-printed PCL scaffold was reinforced with silicone rings and then the tmdECM placed on the lumen followed by hTMSC sheet. Cultured for 3 days. Two groups investigated: 1) scaffold with hTMSC sheet and collagen and 2) scaffold with hTMSC sheets and tmdECM hydrogel.

Higher immunological indicators found in bare and CS scaffolds, similar levels found in PV scaffolds to control. In-growing capillaries found in PV and CS scaffold after 1-2 week post implant. Simple ciliated columnar epithelium and continuous cartilage cell layer found in PV scaffolds, with only flat epithelium and irregular chondrocytes in CS. No epithelial cells and abundant inflammatory cells in submucosa of bare scaffold.

Scaffolds maintained shape, with no inflammation or granulation. Tracheal stenosis and narrowing were mild.

Mild stenosis observed in both groups at 1 month, only at anastomosis site not in middle, but became more severe in group 1 at 2 months compared to group 2. Thin epithelial layer formed above granulation tissue at anastomosis site in group 1, whereas lumen was completely covered in epithelial tissue at 2 months in group 2.

PP: polypropylene; PB: peripheral blood; BM: bone marrow; MSC: mesenchymal stem cell; NA: not applicable; PCL: polycaprolactone; PGA: polyglycolic acid; PLGA: D,L-lactide-co-glycolide; ASC: adipose-derived stem cells; HUVEC: human umbilical vein endothelial cell; hMSC: human mesenchymal stem cell; PET: polyethylene terephthalate; PU: polyurethane; PC: polycarbonate; BM-MNC: bone marrow mononuclear cell; FDM: fused deposition modelling; PLLA: poly(L-lactic acid); P(LLA-CL): poly(L-lactide-co-caprolactone); RTEC: rat tracheal epithelial cell; RTC: rat tracheal chondrocyte; PV: pre-vascularised; CS: cell-seeded; HHP: high hydrostatic pressure; tmdECM: tracheal mucosa derived decellularised extracellular matrix; hTMSC: human inferior turbinate mesenchymal stromal cell. 
studies have been limited by single cell type approaches, poor mechanical characterisation and insufficient re-vascularisation [84].

The rise of 3DP in medical research has seen an exploration into direct cell-laden biomaterial printing, referred to as bioprinting, which holds promise in developing scaffolds that are capable of supporting multiple cell types while being reproducible and patient specific [96]. Bioprinting with cell-loaded bioinks results in poor biomechanical properties because of low bioink melting points and the resultant weak structures [93, 97]. To overcome this, studies have used dual-headed 3D printers to produce structurally strong scaffolds by combining thermoplastic polymers with hydrogels such as alginate and collagen type I hydrogel with PCL [83]. PCL has also been used in combination with sodium alginate hydrogels and when implanted in an animal model growth of ciliated respiratory cells, cartilage formation and vascularisation was observed [82]. Although bioprinting holds potential in fabricating adequate tracheal substitutes, further research is crucial to overcome cell survival outside physiological conditions during the printing process, maintaining an appropriate temperature profile as well as withstanding mechanical stress applied during bioink extrusion [96, 97].

Translation to clinical trials

Pre-clinical outcomes of tissue-engineered tracheal scaffolds

Translation into animal studies has been performed to investigate tissue-engineered tracheas with some limited success (table 3). However, many of these attempts suffer from limited follow-up time of the animals, typically 1-3 months [77, 79]. Early attempts often ended in severe inflammatory response leading to granulation and stenosis of graft or graft failure through infection [76, 78]. Maintaining airtightness and promoting vascularisation significantly adds to the survival prospects of the graft, which can be achieved through pre-implantation strategies $[65,78]$. Wrapping the construct in omentum provides both a vascular network and a source of tissue to seal and maintain airtightness of the graft, thus creating a barrier to bacterial colonisation. Pre-implantation in the abdominal cavity facilitates omentum adherence to the graft and integration of the vascular network [74]. Pre-vascularisation prior to implantation has shown higher survival rate of animals, lower rates of stenosis and increased re-epithelisation [70, 82]. Furthermore, when combined with a cell seeded construct, this technique further supports cell survival and graft integration. Construct pre-seeding has also been reported to increase the survival rate of animals and there was a lack of tracheal stenosis when combining pre-seeding with chondrocytes and pre-vascularisation [70]. Moreover, the inclusion of pre-seeded epithelial cells also enhanced graft acceptance and overall implant success in conjunction with mesenchymal stem cells (MSCs), resulting in full epithelial coverage of the graft and no signs of distress or graft failure in all animals for 3 months occurring [82]. The longest running preclinical study to date was performed in a canine model with a 24-month follow-up using a collagen-coated nitinol frame [74]. The implant was first wrapped in omentum and implanted into the abdominal cavity for 3 weeks, after which it was implanted following a $20 \mathrm{~mm}$ tracheal resection with a survival rate of $80 \%$ reported over 18 months. Histological examination demonstrated stable epithelialisation in a non-stratified monolayer with no secretory glands present and no muscular regeneration, although stenosis was not observed [74]. Other studies using this approach have also observed similar results after 2 months, unfortunately longer-term follow-ups of the study were not published [65]. Several other studies in canines have been followed up to 5-12 months [72, 73].

Attempts to implant synthetic tissue-engineered grafts into humans has resulted in significant controversy and led to several fatalities [25]. Since then, further pre-clinical studies in large animal models have been conducted to better comprehend some of the root cause for these synthetic graft failures [25]. As previously highlighted, the lack of functional epithelium resulted in significant risk of infection, inflammation and/or graft encapsulation. Ongoing inflammation was present in all animals within the study leading to stenosis formation most evident at proximal and distal locations of the graft [25]. Graft seeding with MSCs was associated with delayed onset of respiratory distress showing the importance of establishing a functional epithelium prior to implantation. These in vivo attempts, although mostly short-term studies, have highlighted significant challenges that need to be addressed for a potential tracheal graft. The inclusion of a pre-seeded epithelial layer appears to mitigate bacterial colonisation and the pre-vascularisation of grafts also enhances graft acceptance and survival, however there are still concerns due to the presence of granulation tissue in some attempts.

\section{Clinical outcome of non-TE approaches}

Prostheses

After the limited success of early attempts at treating large tracheal defects, efforts focused on reconstructing the trachea with the use of polymer prosthesis in either solid or porous form. The Neville prosthesis, a solid prothesis manufactured using the synthetic polymer siloxane demonstrated success in 
animal studies but this could not be replicated in humans due to stenosis and graft failure [98-101]. This was caused by the mismatch of mechanical properties of the prosthesis in comparison to the softer surrounding tissue and erosion of adjacent blood vessels and oesophagus due to its rigidity. Furthermore, their inability to become incorporated within the surrounding tissue led to dislodgement during coughing as they become loose and obstructed the airway [49, 90, 100]. Other solid prostheses have consisted of stainless-steel wire [102], polyethylene (PE) [103], tantalum [104] and silicone coupled with a Dacron ${ }^{\mathrm{TM}}$ ring [99].

As issues with solid protheses became apparent, research shifted towards investigating porous prostheses to allow for better ingrowth of cells and tissue formation. The most promising development of porous prostheses arose in 1961 with the success of the Marlex ${ }^{\mathrm{TM}}$ mesh prothesis, a high-density PE and polypropylene, showing 16 months' graft survival and patency in an animal study [101]. However, this prosthesis performed disappointingly in humans due to stenosis and erosion of the surrounding blood vessels [105]. The Marlex prosthesis reinforced the importance of the growth of respiratory epithelium on the inner lumen to act as a protective barrier against foreign bodies in inhaled air [49, 90, 100].

Other attempts at porous protheses have included wire-enforced dermal grafts [106], stainless steel wire mesh [107], silicone with Dacron ${ }^{\mathrm{TM}}$ [98], PE [108] and silicone tubes [109], but these have had similar poor results. Current treatment options for treatment of most tracheobronchical complications have been with commercially available stents including the Ultraflex ${ }^{\mathrm{TM}}$ [110], the silicone-based self-expanding PolyFlex $^{\mathrm{TM}}$ [111] from Boston Scientific, and Novatech's silicone Dunmon ${ }^{\circledR}$ and Gold Studded Stents ${ }^{\circledR}$ [112]. The use of silicone stents has been shown clinically to improve symptoms and quality of life in the vast majority of cases. Although stents have been shown to be tolerated well in the majority of cases, long-term follow-ups have highlighted serious drawbacks. Stent migration, the formation of granulation tissue, obstruction and mucus retention with infections have all been recorded in long-term studies [113-116].

\section{Aortic allografts}

Allograft transplantation for large tracheal defects has primarily focused on two donor tissue sites: tracheas and aortas. Fresh and cryopreserved aortas have been investigated as potential tracheal replacement grafts showing regenerated cartilage and respiratory epithelium in an ovine model, albeit cartilage regeneration in other animal studies has not been observed [117-119]. Nevertheless, the use of aortas as potential donor tissues for trachea replacement was first used in a clinical attempt in a 68-year-old male in 2006, which resulted in severe complications and ultimately death [120]. A cryopreserved aortic allograft was implanted in a 78-year-old male supported with a stent although no cartilage formation was observed and the patient suffered from lower forced expiratory volume [121]. These concerns were also present in another study with six patients using cryopreserved thoracic aortas that were pre-vascularised and stent-supported [122]. Serious complications arose during long-term follow-ups including blood vessels erosion, stent migration and tracheoesophageal fistulas, with no cartilage formation or respiratory epithelium observed in biopsied tissue [119]. The most extensive trial using aortic allografts involved 20 patients with a $76.9 \%$ survival rate after airway transplantation with regeneration of respiratory epithelium and cartilage formation. However, the authors highlighted the need to further assess both the efficacy and the safety of this procedure [123].

\section{Tracheal allografts}

The first successful human tracheal transplant was reported in 1979 showing no signs of rejection or any complication 9 weeks post-op; however, no long-term outcomes were ever made available [124]. Another early success in tracheal allografts was in 1990, when a one-stage tracheal transplantation was successfully conducted but needed to be supported with a stent and extensive immunosuppressive therapy. A follow-up 2 years later reported no issues [125]. Following the early successes, attempts at trachea transplantation have seen very little clinical success [53, 100]. Recent developments by DeLAERE et al. [40, 41, 126] saw the development of a two-step technique in which the donor trachea is revascularised in the patient's forearm before implantation [40, 41, 127]. Despite tissue necrosis being observed in some patients, the technique remains a promising approach $[40,41,100]$.

Although allograft transplantation provides a great airtight analogue structurally, success with allografts has been mixed. The most successful cases used extensive immunosuppressive therapy, which isnot suitable for patients with malignant tumours, furthermore allografts have to be supported with stents due to inadequate mechanical properties and cartilage regeneration [3, 100]. However, stents have been shown to lead to granulation, erosion of adjacent tissue and blood vessels and infection. Revascularisation of allografts is therefore poor and allografts require vascularisation by implantation into a second surgical site, increasing risk of infection and hospitalisation time [33,128]. Although the use of "traditional" organ replacement methods has had little success in tracheal replacement, previous attempts have provided 
TABLE 4 Translation of non-tissue engineering (TE) and TE approaches for tracheal restoration and regeneration in human clinical trials

$\begin{array}{ccccc}\begin{array}{c}\text { Patient(s) } \\ \text { details }\end{array} & \text { Technology } & \text { Material(s) } & \text { Cells } & \text { Procedure details }\end{array}$

\begin{tabular}{|c|c|c|c|c|c|c|}
\hline \multicolumn{7}{|c|}{ Non-TE approaches } \\
\hline $\begin{array}{l}\text { 43-year-old } \\
\text { female }\end{array}$ & Autograft & $\begin{array}{l}\text { Forearm freeflap } \\
\text { supported with an } \\
\text { Ultraflex stent }\end{array}$ & NA & $\begin{array}{l}\text { A freeflap was harvested and wrapped } \\
\text { around a stent after implantation in a } \\
6 \mathrm{~cm} \text { tracheal defect arising for a } \\
\text { carcinoma. }\end{array}$ & $\begin{array}{l}\text { Died } 16 \text { months after the procedure from } \\
\text { pre-existing conditions. }\end{array}$ & [131] \\
\hline $\begin{array}{l}63 \text {-year-old } \\
\text { female }\end{array}$ & Autograft & $\begin{array}{l}\text { Forearm freeflap with an } \\
\text { external mesh support }\end{array}$ & NA & $\begin{array}{l}\text { Radial forearm fasciocutaneous flap with a } \\
\text { Hemashield vascular graft and PolyMax } \\
\text { resorbable mesh. }\end{array}$ & $\begin{array}{l}\text { Patient remains symptom-free at } \\
6 \text { months and has returned to normal } \\
\text { activities. Bronchoscopy at } 6 \text { months } \\
\text { showed slight migration but healed } \\
\text { flap with no obstruction. }\end{array}$ & [132] \\
\hline $\begin{array}{l}16 \text { patients } \\
\text { (37-68 years) }\end{array}$ & Autograft & $\begin{array}{l}\text { Cartilage rib and fascial } \\
\text { skin pad }\end{array}$ & NA & $\begin{array}{l}\text { Segments of the patient's own cartilage } \\
\text { were inserted within a skinpad harvested } \\
\text { from the forearm. Construct was } \\
\text { wrapped around silicone tube for } \\
\text { suturing and implanted within the } \\
\text { defect. }\end{array}$ & $\begin{array}{l}\text { Three deaths following surgical } \\
\text { procedure due to lung infections, } \\
\text { acute respiratory distress syndrome } \\
\text { and myocardial infarction. Long-term } \\
\text { follow-up showed a } 65 \% \text { survival rate. }\end{array}$ & $\begin{array}{l}{[129,} \\
133]\end{array}$ \\
\hline $\begin{array}{l}\text { 21-year-old } \\
\text { male }\end{array}$ & Allotransplantation & Donor cadaveric trachea & $\begin{array}{l}\text { NA or autologous patient } \\
\text { cells }\end{array}$ & $\begin{array}{l}\text { Patient suffering from extensive tracheal } \\
\text { stenosis. A cadaveric trachea with intact } \\
\text { blood supply was implanted } \\
\text { heterotopically into the } \\
\text { sternocleidomastoid muscle for } 3 \text { weeks. } \\
\text { It was then implanted orthopically into } \\
\text { the trachea defect with a vascularised } \\
\text { muscular section of the } \\
\text { sternocleidomastoid. }\end{array}$ & $\begin{array}{l}\text { Integration of the trachea graft and } \\
\text { proper function for } 9 \text { weeks without } \\
\text { evidence of rejection, ischaemia or } \\
\text { infection. }\end{array}$ & [124] \\
\hline $\begin{array}{l}\text { 24-year-old } \\
\text { female }\end{array}$ & Allotransplantation & Donor cadaveric trachea & NA & $\begin{array}{l}\text { Patient suffering from tracheal stenosis and } \\
\text { third stage respiratory insufficiency. The } \\
\text { allograft was implanted and wrapped } \\
\text { with omentum and the patient was } \\
\text { placed on immunosuppressive therapy. }\end{array}$ & $\begin{array}{l}\text { Uneventful postoperative course with } \\
\text { signs of graft rejection, necrosis, } \\
\text { bacterial and viral infection which lead } \\
\text { to the need of silicon endoprosthesis. } \\
\text { Signs for rejection reduced and 1-year } \\
\text { follow-up suggested patient was still } \\
\text { alive with a restored tracheal lumen. }\end{array}$ & [125] \\
\hline $\begin{array}{l}\text { Four patients } \\
\text { (17-64 years; } \\
\text { three males, } \\
\text { one female) }\end{array}$ & Allotransplantation & $\begin{array}{l}\text { Human cadaveric } \\
\text { trachea }\end{array}$ & $\begin{array}{l}\text { Recipient's buccal mucosa } \\
\text { and/or ingrown recipient } \\
\text { cells }\end{array}$ & $\begin{array}{l}\text { Patients suffering from tracheal stenosis or } \\
\text { tracheal chondrosarcoma. Decellularised } \\
\text { tracheas were implanted in the forearm } \\
\text { and grafted with buccal mucosa or } \\
\text { wrapped in forearm fascia to improve } \\
\text { vascularisation. }\end{array}$ & $\begin{array}{l}\text { Tracheal necrosis after withdrawal of } \\
\text { immunosuppression and poor } \\
\text { vascularisation around the grafts } \\
\text { leading to partial loss of the } \\
\text { allotransplant in three patients while } \\
\text { additional approaches for recipient cell } \\
\text { repopulation of the construct in one } \\
\text { patient allowed a vascularised } \\
\text { allotransplant and normal airways } \\
6 \text { months after transplantation. }\end{array}$ & [128] \\
\hline
\end{tabular}




\section{TABLE 4 Continued}

Patient(s)

Technology

Material(s)

Procedure details

Outcome

$\begin{array}{lll}\begin{array}{l}\text { 68-year-old } \\ \text { male }\end{array} & \begin{array}{c}\text { Stent-supported } \\ \text { aortic autograft }\end{array} & \begin{array}{c}\text { Aorta autograft and } \\ \text { silicone Dumon stent }\end{array}\end{array}$

silicone Dumon stent
Fresh or cryopreserved

aortic grafts and silicone

stent

17-52 years:

one female)

$\begin{array}{lcc}\begin{array}{l}\text { 78-year-old } \\ \text { male }\end{array} & \begin{array}{c}\text { Stent-supported } \\ \text { aortic allograft }\end{array} & \begin{array}{c}\text { Cryopreserved aortic } \\ \text { graft and custom-made } \\ \text { nitinol stent }\end{array} \\ \begin{array}{l}\text { 20 patients } \\ \text { (24-79 years; }\end{array} & \begin{array}{c}\text { Stent-supported } \\ \text { aortic allograft }\end{array} & \begin{array}{c}\text { Cryopreserved aortic } \\ \text { graft and custom-made } \\ \text { nitinol stent }\end{array}\end{array}$

seven

females)

\section{TE approaches}

26-year-old

male
Stent-supported

aortic allograft jejunum
NA

Patient presenting tracheal squamous cell
carcinoma. A $7 \mathrm{~cm}$ abdominal autograft was harvested and replaced

with a Dracon graft. The aortic graft was implanted coupled with a silicone

Dumon stent to avoid aortic wall injury.

Patients suffering from mucoepidermoid and adenoid cystic carcinoma. Aortic allografts were wrapped with well

vascularised pectoral muscle or

thymopericardial fat flaps and implanted using a silicone stent.

Patient suffering from extensive

bronchopulmonary malignant tumour pre-treated with chemotherapy. Lung cancer was resected, and a stent-supported graft was implanted.

Patients presenting proximal lung tumours and malignant or benign lesions of the trachea and bronchi. Radial tumour resections were performed and the stent-supported graft was implanted and covered circumferentially with a local muscle flap.

Recipient's mvECs and skMCs jejunum containin
autologous cell population
Patient suffering from extensive tracheal and oesophageal defect. Porcine cell-free vascularised scaffolds were obtained through a decellularisation process and seeded to ensure re-endothelialisation with recipient's cell prior to implantation into the $5 \times 2 \mathrm{~cm}$ defect. The construct was characterised prior to implantation to ensure safety and maximum performance.
Granulation tissue formation led to acute respiratory distress syndrome which was treated by introduction of an additional tracheal stent. Stent was removed due to migration albeit no airway collapse was detected. Pneumonia, respiratory distress and pneumothorax lead to death of patient due to septic shock.

Complete resection achieved in $83 \%$ of patients. Major morbidity, fistulas and uneventful outcomes. All grafts showed adequate vascularisation and four patients are disease-free.

Well-functioning re-implanted lobe found 1 year post procedure. Patient recovered baseline activity with satisfying health quality of life.

Patient follow-up of 90 days detecting a $5 \%$ mortality rate. No adverse effect of the surgical technique used showing a $76.5 \%$ survival at a median follow-up of 3 years and 11 months. Regeneration of cartilage and respiratory epithelium observed.

The postoperative period was uneventful and the transplanted bioengineered construct was fully integrated presenting a fully functional respiratory epithelium on the lining of the airway without tissue scar formation or tissue dedifferentiation. 


\begin{tabular}{|c|c|c|c|c|c|c|}
\hline $\begin{array}{c}\text { Patient(s) } \\
\text { details }\end{array}$ & Technology & Material(s) & Cells & Procedure details & Outcome & Ref. \\
\hline $\begin{array}{l}\text { 12-year-old } \\
\text { male }\end{array}$ & Decellularisation & $\begin{array}{l}\text { Human decellularised } \\
\text { trachea containing } \\
\text { autologous stem-cell } \\
\text { populations }\end{array}$ & $\begin{array}{l}\text { Recipient's CD34 or } \\
\text { CD45wk haematopoietic } \\
\text { stem cells and } \mathrm{CD} 73^{+} \\
\mathrm{CD}^{+} 0^{+}, \mathrm{CD} 105^{+}, \mathrm{CD} 117^{+} \text {or } \\
\mathrm{CD} 45^{+} \mathrm{MSCs}\end{array}$ & $\begin{array}{l}\text { Patient born with long-segmental tracheal } \\
\text { stenosis and pulmonary sling. A } \\
\text { decellularised cadaveric trachea was } \\
\text { saturated with the recipient's stem cell } \\
\text { suspension and implanted coupled with } \\
\text { a PDO stent. The construct was } \\
\text { saturated with hrEPO, G-CSF and TGF- } \beta \text {. }\end{array}$ & $\begin{array}{l}\text { The graft was vascularised } 1 \text { week } \\
\text { following surgery, but epithelium } \\
\text { restoration was not seen until } 1 \text { year } \\
\text { post-implantation. Biomechanical } \\
\text { strength was not appropriate until } \\
18 \text { months. Functional airway found at } \\
2 \text { years follow-up. Patient free from } \\
\text { medical intervention in a 4-year } \\
\text { follow-up study. }\end{array}$ & $\begin{array}{l}{[135,} \\
136]\end{array}$ \\
\hline $\begin{array}{l}15 \text {-year-old } \\
\text { female }\end{array}$ & Decellularisation & $\begin{array}{l}\text { Human decellularised } \\
\text { trachea containing } \\
\text { autologous stem-cell } \\
\text { populations }\end{array}$ & $\begin{array}{l}\text { Recipient's BM-MSCs and } \\
\text { nasal-derived epithelial } \\
\text { cells }\end{array}$ & $\begin{array}{l}\text { Patient presenting critical tracheal stenosis. } \\
\text { A decellularised cadaveric trachea was } \\
\text { pre-seeded in vitro in a custom-made } \\
\text { bioreactor before implantation. }\end{array}$ & $\begin{array}{l}\text { Patency of the graft and intact } \\
\text { anastomoses following implantation. } \\
\text { Tracheal graft narrowing was observed } \\
13 \text { days after surgery leading to } \\
\text { ventilator compromise and respiratory } \\
\text { arrest, which finally resulted in } \\
\text { cerebral hypoxic injury and oedema. }\end{array}$ & [137] \\
\hline $\begin{array}{l}\text { 78-year-old } \\
\text { female }\end{array}$ & TE scaffold & $\begin{array}{c}\text { Marlex mesh tube } \\
\text { covered with a collagen } \\
\text { type I and III (porcine } \\
\text { dermal atelocollagen) } \\
\text { sponge }\end{array}$ & NA & $\begin{array}{l}\text { Patient showing right lobe thyroid gland } \\
\text { tumour and consequent tracheal } \\
\text { invasion. The construct was implanted } \\
\text { and injected with autologous venous } \\
\text { blood for air-tightness, water-tightness } \\
\text { and endogenous factors release. }\end{array}$ & $\begin{array}{l}\text { The bioengineered construct supported } \\
\text { the epithelial growth } 2 \text { months after } \\
\text { surgery, proper epithelialisation was } \\
\text { observed } 7 \text { months later and was } \\
\text { completely covered with respiratory } \\
\text { epithelium } 20 \text { months after surgery. } \\
\text { Epithelialisation continued to cover the } \\
\text { trachea for } 2 \text { years showing no } \\
\text { complication. }\end{array}$ & [138] \\
\hline $\begin{array}{l}\text { Four patients } \\
\text { ( } 59-78 \text { years; } \\
\text { two male, } \\
\text { two female) }\end{array}$ & TE scaffold & $\begin{array}{c}\text { Marlex mesh tube } \\
\text { covered with a collagen } \\
\text { type I and III (porcine } \\
\text { dermal atelocollagen) } \\
\text { sponge }\end{array}$ & NA & $\begin{array}{l}\text { Patients with history of tracheotomy, } \\
\text { stenosis and thyroid cancer. The } \\
\text { construct was implanted and injected } \\
\text { with autologous venous blood. }\end{array}$ & $\begin{array}{l}\text { Observation period of } 8-34 \text { months } \\
\text { showed sufficient epithelialisation of } \\
\text { the construct without obstructions. }\end{array}$ & [139] \\
\hline $\begin{array}{l}\text { Three } \\
\text { patients (39- } \\
71 \text { years; one } \\
\text { male, two } \\
\text { female) }\end{array}$ & TE scaffold & $\begin{array}{l}\text { Marlex (PP) mesh tube } \\
\text { covered with a collagen } \\
\text { type I and III (porcine } \\
\text { dermal atelocollagen) } \\
\text { sponge }\end{array}$ & NA & $\begin{array}{l}\text { Patients suffering from stenosis of the } \\
\text { trachea and/or cricoids caused by } \\
\text { endotracheal intubations. Two-stage } \\
\text { operation for the resection of the } \\
\text { stenotic regions and implantation of the } \\
\text { construct followed by delivery of venous } \\
\text { blood and b-FGF to the cartilage defect. }\end{array}$ & $\begin{array}{l}\text { All patients were able to breath after } \\
\text { implantation and showed no } \\
\text { discomfort in daily activities. Enough } \\
\text { air space in the trachea was observed } \\
6 \text { months after implantation. }\end{array}$ & [140] \\
\hline $\begin{array}{l}\text { Infant } \\
\text { ( } 2 \text { months } \\
\text { old) }\end{array}$ & 3DP & $\mathrm{PCL}$ & NA & $\begin{array}{l}\text { Patient suffering from TBM. A } \\
\text { custom-designed and custom-fabricated } \\
\text { resorbable 3DP airway splint was } \\
\text { implanted and predicted to be fully } \\
\text { resorbed within } 3 \text { years. }\end{array}$ & $\begin{array}{l}21 \text { days after the procedure ventilator } \\
\text { support was ended and patient was } \\
\text { discharged. } 1 \text { year after surgery a } \\
\text { patent left mainstem bronchus was } \\
\text { observed and no unforeseen problems } \\
\text { related to the splint arose. }\end{array}$ & [141] \\
\hline
\end{tabular}




\section{TABLE 4 Continued}

Technology

(nt

details

Cells

Procedure details

Outcome

Ref.

\begin{tabular}{|c|c|c|c|c|c|c|}
\hline $\begin{array}{l}\text { Three infants } \\
\text { (3- } \\
16 \text { months; } \\
\text { three males) }\end{array}$ & $3 \mathrm{DP}$ & $\mathrm{PCL}$ & NA & $\begin{array}{l}\text { Patients suffering from TBM. 3DP splints } \\
\text { were customised for each patients needs } \\
\text { using CT imaging and CAD modelling } \\
\text { software. }\end{array}$ & $\begin{array}{l}\text { At the time of publication, all patients } \\
\text { did not show signs of airway disease } \\
\text { showing continued growth of the } \\
\text { primary airways. }\end{array}$ & [78] \\
\hline $\begin{array}{l}\text { 46-year-old } \\
\text { female }\end{array}$ & $3 \mathrm{DP}$ & PCL & NA & $\begin{array}{l}\text { Patient with TBM. 3DP splint designed } \\
\text { using CT imaging and modelling } \\
\text { software was implanted wrapped in an } \\
\text { artificial pleural patch. }\end{array}$ & $\begin{array}{l}2 \text { weeks after surgery the patient was } \\
\text { discharged from hospital with } \\
\text { increased tracheal inner diameter and } \\
\text { cross-sectional area. Breathing and } \\
\text { physical strength improvement in a } \\
\text { 3-month follow-up. No adverse } \\
\text { reaction or toxicity was found. }\end{array}$ & [142] \\
\hline Young female & $3 D P$ & PEKK & NA & $\begin{array}{l}\text { Patient suffering from acquired TBM. A } \\
\text { PEKK splint was design using CT imaging } \\
\text { and modelling software. PEKK was } \\
\text { chosen over PCL for its superior } \\
\text { properties and suitability for } \\
\text { manufacturing. }\end{array}$ & $\begin{array}{l}\text { Restoration of tracheal patency and } \\
\text { patient remains asymptomatic, no } \\
\text { further complications or } \\
\text { hospitalisations were recorded. }\end{array}$ & [143] \\
\hline $\begin{array}{l}15 \text { patients } \\
\text { (3-25 } \\
\text { months; six } \\
\text { male, nine } \\
\text { female) }\end{array}$ & $3 D P$ & PCL & NA & $\begin{array}{l}\text { Patients suffering from TBM and airway } \\
\text { erosion. 3DP split designed using CT } \\
\text { imaging and modelling software. A total } \\
\text { of } 29 \text { splints ( } 10 \text { tracheal, } 12 \text { left } \\
\text { bronchus and seven right bronchus) } \\
\text { were implanted with the help of PP } \\
\text { sutures. }\end{array}$ & $\begin{array}{l}\text { No patients required splint removal or } \\
\text { re-operation. Three mortalities were } \\
\text { recorded. At } 8.5 \text {-month follow-up, } 11 \\
\text { patients were living at home. }\end{array}$ & [77] \\
\hline
\end{tabular}

NA: not applicable; mvEC: microvascular endothelial cell; skMC: skeletal muscle cell; MSC: mesenchymal stem cells; PDO: polydioxanone; hrEPO: human recombinant erythropoietin; G-CSF: granulocyte-colony stimulating factor; TGF- $\beta$ : transforming growth factor- $\beta$; BM-MNC: bone marrow mononuclear cell; PP: polypropylene; b-FGF: basic fibroblast growth factor; PCL: polycaprolactone; TBM: tracheobronchomalacia; 3DP: 3D printing-2; CT: computed tomography: CAD: computer-aided design; PEKK: polyetherketoneketone. 
insight on the requirements for a successful tracheal graft. In more recent years, research has shifted to overcoming these challenges by using TE technology.

\section{Tracheal autografts}

The use of a patient's own tissue has also been investigated clinically for tracheal transplant. This two-step surgical approach uses the patient's own cartilage, which are segments that have been harvested from their ribs [129]. These segments are inserted within a fascial skin pad, also harvested from the patient's forearm, and wrapped around a temporary silicone tube to suture together a tracheal conduit for implantation. Great care is taken to keep the radial artery and superficial and deep drainage veins of the skin pad intact to revascularise the conduit upon implantation. This technique alleviates the need for immunosuppressants by not introducing synthetic or foreign bodies within patients [129, 130]. However, due to the absence of a respiratory epithelial layer and use of autologous cartilage tissue, tracheal autografts are not suitable for all patients. Autograft transplantation is based on acceptable respiratory function and healthy cartilage tissue as secretion obstruction and cartilage fracture can cause implant failure [129, 130].

\section{Clinical translation of TE approaches}

Few TE approaches for tracheal regeneration have made it to human clinical trials, but significant findings have been demonstrated in TE that have reached this milestone (table 4). The first report of a successful case dates to 2005 [138] when a Marlex prostheses covered in type I and II porcine-derived collagen was successfully implanted and demonstrated regeneration of the respiratory epithelium. Histological examination showed the successful incorporation of the scaffold within surrounding tissues, regenerating the subglottic and tracheal epithelium and achieving optimal epithelial growth 20 months post-operation covering the implanted material. Moreover, mechanical studies confirmed the patency of the airway [138]. This technique was further employed in a wider set of patients demonstrating a well-epithelialised lumen with no apparent airway obstructions in follow-up examinations making it a promising approach to treat tracheal stenosis and malignancy [139]. The combination of this approach with growth factor delivery to enhance graft performance showing optimal regeneration in all patients was also evaluated. Addition of basic fibroblast growth factor (bFGF) to the cartilage defect, was hypothesised to improve blood vessel formation, and maintained airway patency in all patients. However, the use of bFGF may be of limited use in cases of cancer resection due to increased tumour recurrence [140].

Surgical implantation of DTs was first successfully performed in 2010. A cadaveric trachea was decellularised, implanted in the forearm of the recipient and seeded with buccal mucosa to enhance vascularisation prior to implantation [127]. This approach was further explored with four additional patients, but tracheal necrosis and poor vascularisation hampered the outcome of this clinical trial [139]. In another set of attempts, cadaveric tracheas were decellularised and pre-seeded prior to implantation with the recipient's stem cells and growth factors to ensure vascularisation of the graft and to promote chondrogenesis with mixed outcomes due to graft narrowing. However, one DT successfully restored epithelium around the damaged section with no further complications observed in a 4-year follow-up study [135-137]. Even though some of these TE approaches have demonstrated a certain degree of promise, further and more extensive follow-up studies and a wider number of patients will be needed in order to ensure this technology can become an alternative approach for tracheal restoration and regeneration.

As highlighted earlier, 3DP has emerged as a promising technique to treat tracheal defects in paediatric patients as 3D printed airway splints have been graded FDA approval recently [144]. The implantation of a 3D-printed splint to treat a severe case of TBM was first reported in 2013 [141] and, since then, has been applied to a wider set of patients reporting low general mortalities [91, 92, 142, 143]. However, implantation of 3D-printed airway splints has been mostly restricted to paediatric patients suffering from TBM. In this way, airway growth is guided during the early stages of development and leads to natural resolution of TBM. Apart from paediatric patients, there is only one reported attempt of using a 3D-printed airway splint in an adult individual with maintained airway patency 3 months after the procedure. Additionally, custom-made airway stents by a number of groups, including for example researchers at the Toulouse University Hospital and AnatomikModeling have shown promise in ongoing clinical trials. Patient-specific sacrificial moulds were 3D-printed from CT-scan images to create patient-specific tracheal prosthetics from silicone elastomer. Several patients have successfully received these implants in clinical trials, with reports of improved quality of life and no complications thus far. This personalised approach shows promise, but long-term results have not been made available as of yet [145]. Albeit early promising attempts to use 3D-printing technologies to overcome tracheal stenosis and malignancies are emerging, there is a need to extend follow-up studies to asses splint resorption as well as establish optimal designs and validated manufacturing processes in order to assure safety and efficacy during future clinical trials [146]. 
The first step for the successful development of a tissue-engineered trachea is a thorough characterisation of the proposed construct in terms of material performance, degradation, mechanical strength and flexibility. Moreover, the manufacturing process employed should allow where possible the manufacturing of individualised constructs to meet specific patient's needs, in addition to being anti-bacterial, anti-proliferative, anti-tussive and non-migrating [2]. One of the main limitations in tracheal TE is the lack of consistent and relevant data of airway biomechanics, lack of standardised tests to assess mechanical properties as well as a wide range of mechanical values that a potential graft should possess as seen in table 2 [147]. Therefore, a standardised procedure for assessing mechanical strength should be developed to better understand the needs of a TE graft. This standard procedure should also include the differences in tracheal biomechanics between different age-group patients as well as gender differences [27, 148].

Several scaffolds have been designed to support epithelialisation in a graft as the lining of a mature pseudostratified epithelium is needed in order to avoid stenosis, tissue outgrowth and granulation [22]. Different approaches have been investigated both in vitro and in vivo but the lack of long-term assessment and the granulation and inflammatory reaction following transplantation have hindered further translation. This highlights the need for better TE approaches that support full and functional re-epithelialisation early on in the development graft process [81, 84, 149].

Vascularisation of a tissue-engineered trachea stands as the most important challenge that needs to be overcome for $\mathrm{TE}$ tracheal scaffolds to translate into clinical trials. It has been widely reported that vascularisation is mandatory in order to achieve a functional graft as the lack of a vasculature formation will inevitably lead to high morbidity, poor outcomes and no benefit for the patient [41]. Although several approaches have shown promise in revascularising the implanted graft, further long-term assessment of the patients and an increased number of trials is needed to demonstrate that these approaches are suitable for tracheal regeneration and restoration $[127,128,135,136]$.

Overall, the few TE approaches to tracheal replacement that have made it to clinical trials have provided substantial insight on the necessary requirements for a graft to succeed. Due to the complexity of the trachea's anatomy, a number of challenging properties must be met collectively, and data gained from both pre-clinical and clinical trials have provided a greater understanding on the advantages and pitfalls of certain techniques and methods.

\section{Conclusion}

Several TE strategies have emerged during the last decade with the goal of developing a functional scaffold capable of regenerating tracheal tissues. However, clinical translation of TE technologies has been very limited and on a small scale to date. Furthermore, poor mechanical properties, insufficient vascularisation of the implanted tracheas over time and inadequate re-epithelialisation have hindered graft performance [41]. Moreover, both animal and clinical studies lack long-term assessments of graft performance, which are needed to fully assess the feasibility of the approach. Therefore, any construct being developed for tracheal regeneration must provide the required mechanical properties as well as support the formation of a respiratory epithelium and a network of vascular capillaries to avoid graft contamination, granulation and tissue necrosis.

Tracheal replacement has lately become a focus of interest for TE with the development of promising prototypes showing that epithelialisation and vascularisation of the grafts can be achieved through different procedures. Moreover, some of these TE grafts have made their way through clinical trials with promising outcomes and delivering crucial insight on the necessary properties needed for a tracheal graft to succeed. Overcoming limitations involving mechanical properties, epithelialisation and vascularisation will lead to a wider use of TE tracheal substitutes that could become a turning point in how tracheal stenosis and damage is clinically addressed.

Provenance: Submitted article, peer reviewed.

Conflict of interest: None declared.

Support statement: The authors acknowledge the funding received for this research under the Science Foundation Ireland (SFI) Centre for Research in Medical Devices (CURAM) and the European Regional Development Fund (Grant 13/RC/2073); and by the SFI-funded AMBER centre (Grant 17/RC-PhD/3477). 
References

1 Boazak EM, Auguste DT. Trachea mechanics for tissue engineering design. ACS Biomater Sci Eng 2018; 4: $1272-1284$.

2 Gao M, Zhang H, Dong W, et al. Tissue-engineered trachea from a 3D-printed scaffold enhances whole-segment tracheal repair. Sci Rep 2017; 7: 5246.

3 Grillo HC. Tracheal replacement: a critical review. Ann Thorac Surg 2002; 73: 1995-2004.

4 Grillo HC. Slide tracheoplasty for long-segment congenital tracheal stenosis. Ann Thorac Surg 1994; 58: 613-621.

5 Prokakis C, Koletsis EN, Dedeilias P, et al. Airway trauma: a review on epidemiology, mechanisms of injury, diagnosis and treatment. J Cardiothorac Surg 2014; 9: 117.

6 Johnson SB. Tracheobronchial injury. Semin Thorac Cardiovasc Surg 2008; 20: 52-57.

7 Fiorelli A, Cascone R, Di Natale D, et al. Endoscopic treatment with fibrin glue of post-intubation tracheal laceration. J Vis Surg 2017; 3: 102.

8 Miñambres E, Burón J, Ballesteros MA, et al. Tracheal rupture after endotracheal intubation: a literature systematic review. Eur J Cardio Thorac Surg 2009; 35: 1056-1062.

9 Madariaga MLL, Gaissert HA. Overview of malignant tracheal tumors. Ann Cardiothorac Surg 2018; 7 : 244-254.

10 Urdaneta Al, Yu JB, Wilson LD. Population based cancer registry analysis of primary tracheal carcinoma. Am J Clin Oncol 2011; 34: 32-37.

11 Kandaswamy C, Balasubramanian V. Review of adult tracheomalacia and its relationship with chronic obstructive pulmonary disease. Curr Opin Pulm Med 2009; 15: 113-119.

12 Esteller-Moré E, Ibañez J, Matiñó E, et al. Prognostic factors in laryngotracheal injury following intubation and/or tracheotomy in ICU patients. Eur Arch Otorhinolaryngol 2005; 262: 880-883.

13 Sarper A, Ayten A, Eser I, et al. Tracheal stenosis after tracheostomy or intubation: review with special regard to cause and management. Tex Heart Inst J 2005; 32: 154-158.

14 Nassar N, Leoncini E, Amar E, et al. Prevalence of esophageal atresia among 18 international birth defects surveillance programs. Birth Defects Res A Clin Mol Teratol 2012; 94: 893-899.

15 Ergun S, Tewfik T, Daniel S. Tracheal agenesis: a rare but fatal congenital anomaly. Mcgill J Med 2011; 13: 10.

16 Shaw-Smith C. Oesophageal atresia, tracheo-oesophageal fistula, and the VACTERL association: review of genetics and epidemiology. J Med Genet 2006; 43: 545-554.

17 Mattioli F, Marchioni A, Andreani A, et al. Post-intubation tracheal stenosis in COVID-19 patients. Eur Arch Otorhinolaryngol 2021; 278: 847-848.

18 Lee P, Kupeli E, Mehta AC. Airway stents. Clin Chest Med 2010; 31: 141-150.

19 Grewal HS, Dangayach NS, Ahmad U, et al. Treatment of tracheobronchial injuries: a contemporary review. Chest 2019; 155: 595-604.

20 Nagappan R, Parkin G, Wright CA, et al. Adult long-segment tracheal stenosis attributable to complete tracheal rings masquerading as asthma. Crit Care Med 2002; 30: 238-240.

21 Knight DA, Holgate ST. The airway epithelium: structural and functional properties in health and disease. Respirology 2003; 8: 432-446.

22 Den Hondt M, Vanaudenaerde B, Verbeken E, et al. Requirements for successful trachea transplantation: a study in the rabbit model. Plast Reconstr Surg 2018; 141: 845e-856e.

23 Wachsmuth L, Söder S, Fan Z, et al. Immunolocalization of matrix proteins in different human cartilage subtypes. Histol Histopathol 2006; 21: 477-485.

24 Teng Z, Trabelsi O, Ochoa I, et al. Anisotropic material behaviours of soft tissues in human trachea: an experimental study. J Biomech 2012; 45: 1717-1723.

25 Pepper V, Best CA, Buckley $\mathrm{K}$, et al. Factors influencing poor outcomes in synthetic tissue-engineered tracheal replacement. Otolaryngol Head Neck Surg 2019; 161: 458-467.

26 Mow VC, Kuei S, Lai WM, et al. Biphasic creep and stress relaxation of articular cartilage in compression: theory and experiments. J Biomech Eng 1980; 102: 73-84.

27 Safshekan F, Tafazzoli-Shadpour M, Abdouss M, et al. Mechanical characterization and constitutive modeling of human trachea: age and gender dependency. Materials 2016; 9: 456.

28 Bagnoli P, Acocella F, Di Giancamillo M, et al. Finite element analysis of the mechanical behavior of preterm lamb tracheal bifurcation during total liquid ventilation. J Biomech 2013; 46: 462-469.

29 Sarma P, Pidaparti R, Meiss RA, et al. Anisotropic properties of tracheal smooth muscle tissue. J Biomed Mater Res A 2003; 65: 1-8.

30 Rains J, Bert J, Roberts C, et al. Mechanical properties of human tracheal cartilage. J Appl Physiol (1985) 1992; 72: 219-225.

31 Hoffman B, Martin M, Brown BN, et al. Biomechanical and biochemical characterization of porcine tracheal cartilage. Laryngoscope 2016; 126: E325-E331. 
Trabelsi O, Del Palomar AP, López-Villalobos J, et al. Experimental characterization and constitutive modeling of the mechanical behavior of the human trachea. Med Eng Phys 2010; 32: 76-82.

Wang J-Y, Mesquida P, Pallai P, et al. Dynamic properties of human bronchial airway tissues. arXiv 2011; preprint [arXiv:1111.5645]

Mansfield EG, Greene Jr VK, Auguste DTJAb. Patterned, tubular scaffolds mimic longitudinal and radial mechanics of the neonatal trachea. Acta Biomater 2016; 33: 176-182.

Sun F, Jiang Y, Xu Y, et al. Genipin cross-linked decellularized tracheal tubular matrix for tracheal tissue engineering applications. Sci Rep 2016; 6: 24429.

Park HS, Lee JS, Jung H, et al. An omentum-cultured 3D-printed artificial trachea: in vivo bioreactor. Artif Cells Nanomed Biotechnol 2018; 46: Suppl. 3, S1131-S1140.

Walles T, Giere B, Hofmann M, et al. Experimental generation of a tissue-engineered functional and vascularized trachea. J Thorac Cardiovasc Surg 2004; 128: 900-906.

Acocella F, Brizzola S. 12 - Tracheal tissue regeneration. In: Bosworth LA, Downes S, eds. Electrospinning for Tissue Regeneration. Sawston, Woodhead Publishing, 2011; pp. 242-279.

Delaere P, Van Raemdonck D. Tracheal replacement. J Thorac Dis 2016; 8: Suppl 2, S186-S196.

Delaere P, Van Raemdonck D, Vranckx J. Tracheal transplantation. Intensive Care Med 2019; 45: 391-393.

Trendelenburg F. Beiträge zu den Operationen an den Luftwegen. Arch Klin Chir 1871; 12: 112-133.

Gluck T, Zeller A. Die prophylaktische Resektion der Trachea. Arch Klin Chir 1881; 26: 427-436.

Colley F. Die Resektion der Trachea. Deutsche Ztschr Chir 1895; 40: 150-162.

Küster E. Über narbige Stenosen der Trachea. Zentralbl Chir 1886; 13: 759-760.

LeJeune F, Owens N. Chronic laryngeal stenosis. Ann Otol Rhinol Laryngol 1935; 44: 354-363.

Levit H. Repair of tracheal defects with free grafts of fascia lata. Arch F Klin Chir 1912; 97: 686.

Crafoord C, Lindgren AGH. Mucous and salivary gland tumours in the bronchi and trachea, formerly generally called bronchial adenomata. Acta Chirurgica Scand 1945; 92: U506.

Virk JS, Zhang H, Nouraei R, et al. Prosthetic reconstruction of the trachea: a historical perspective. World $J$ Clin Cases 2017; 5: 128-133.

Scherer MA, Ascherl R, Geissdörfer K, et al. Experimental bioprosthetic reconstruction of the trachea. Arch Otorhinolaryngol 1986; 243: 215-223.

Jana T, Khabbaz E, Bush CM, et al. The body as a living bioreactor: a feasibility study of pedicle flaps for tracheal transplantation. Eur Arch Otorhinolaryngol 2013; 270: 181-186.

Kato R, Onuki AS, Watanabe M, et al. Tracheal reconstruction by esophageal interposition: an experimental study. Ann Thorac Surg 1990; 49: 951-954.

Udelsman BV, Eaton J, Muniappan A, et al. Repair of large airway defects with bioprosthetic materials. J Thorac Cardiovasc Surg 2016; 152: 1388-1397.

Temenoff JS, Mikos AG. Review: tissue engineering for regeneration of articular cartilage. Biomaterials 2000; 21: 431-440.

Ramos T, Moroni L. Tissue engineering and regenerative medicine 2019: the role of biofabrication-a year in review. Tissue Eng C Methods 2019; 26: 91-106.

Kreimendahl $\mathrm{F}$, Ossenbrink S, Köpf $\mathrm{M}$, et al. Combination of vascularization and cilia formation for three-dimensional airway tissue engineering. J Biomed Mater Res A 2019; 107: 2053-2062.

Hamilton N, Bullock AJ, Macneil S, et al. Tissue engineering airway mucosa: a systematic review. Laryngoscope 2014; 124: 961-968.

Zhang H, Fu W, Xu Z. Re-epithelialization: a key element in tracheal tissue engineering. Regen Med 2015; 10 : 1005-1023.

Lee SJ, Choi JS, Eom MR, et al. Dexamethasone loaded bilayered 3D tubular scaffold reduces restenosis at the anastomotic site of tracheal replacement: in vitro and in vivo assessments. Nanoscale 2020; 12: 4846-4858.

Xu Y, Li D, Yin Z, et al. Tissue-engineered trachea regeneration using decellularized trachea matrix treated with laser micropore technique. Acta Biomater 2017; 58: 113-121.

Hong P, Bezuhly M, Graham ME, et al. Efficient decellularization of rabbit trachea to generate a tissue engineering scaffold biomatrix. Int J Pediatr Otorhinolaryngol 2018; 112: 67-74.

Ohno M, Fuchimoto $\mathrm{Y}$, Hsu HC, et al. Airway reconstruction using decellularized tracheal allografts in a porcine model. Pediatr Surg Int 2017; 33: 1065-1071.

Siddiqi S, de Wit R, Timman S, et al. Tissue engineering of the trachea: what is the hold-up? MOJ Cell Science Rep 2017; 4: 13-17.

Rehmani SS, Al-Ayoubi AM, Ayub A, et al. Three-dimensional-printed bioengineered tracheal grafts: preclinical results and potential for human use. Ann Thorac Surg 2017; 104: 998-1004.

Kim J, Suh SW, Shin JY, et al. Replacement of a tracheal defect with a tissue-engineered prosthesis: early results from animal experiments. J Thorac Cardiovasc Surg 2004; 128: 124-129.

Best CA, Pepper VK, Ohst D, et al. Designing a tissue-engineered tracheal scaffold for preclinical evaluation. Int J Pediatr Otorhinolaryngol 2018; 104: 155-160. 
Jun I, Han HS, Edwards JR, et al. Electrospun fibrous scaffolds for tissue engineering: viewpoints on architecture and fabrication. Int J Mol Sci 2018; 19: 745.

Kang Y, Wang C, Qiao Y, et al. Tissue-engineered trachea consisting of electrospun patterned Sc-PLA/GO-g-IL fibrous membranes with antibacterial property and 3D-printed skeletons with elasticity. Biomacromolecules 2019; 20: 1765-1776.

Townsend JM, Ott LM, Salash JR, et al. Reinforced electrospun polycaprolactone nanofibers for tracheal repair in an in vivo ovine model. Tissue Eng Part A 2018; 24: 1301-1308.

Wu T, Zheng H, Chen J, et al. Application of a bilayer tubular scaffold based on electrospun poly(l-lactideco-caprolactone)/collagen fibers and yarns for tracheal tissue engineering. J Mater Chem B 2017; 5: 139-150. O'Leary C, Soriano L, Fagan-Murphy A, et al. The fabrication and in vitro evaluation of retinoic acid-loaded electrospun composite biomaterials for tracheal tissue regeneration. Front Bioeng Biotechnol 2020; 8: 190.

Kim JH, Kong WH, Kim JG, et al. Possibility of skin epithelial cell transdifferentiation in tracheal reconstruction. Artif Organs 2011; 35: 122-130.

Nakamura T, Sato T, Araki M, et al. In situ tissue engineering for tracheal reconstruction using a luminar remodeling type of artificial trachea. J Thorac Cardiovasc Surg 2009; 138: 811-819.

Sakaguchi Y, Sato T, Muranishi Y, et al. Development of a novel tissue-engineered nitinol frame artificial trachea with native-like physical characteristics. J Thorac Cardiovasc Surg 2018; 156: 1264-1272.

Xia D, Jin D, Wang Q, et al. Tissue-engineered trachea from a 3D-printed scaffold enhances whole-segment tracheal repair in a goat model. J Tissue Eng Regen Med 2019; 13: 694-703.

Vacanti CA, Paige KT, Kim WS, et al. Experimental tracheal replacement using tissue-engineered cartilage. J Pediatr Surg 1994; 29: 201-204.

Go T, Jungebluth P, Baiguero S, et al. Both epithelial cells and mesenchymal stem cell-derived chondrocytes contribute to the survival of tissue-engineered airway transplants in pigs. J Thorac Cardiovasc Surg 2010; 139: 437-443.

Lin C-H, Hsu S-H, Huang C-E, et al. A scaffold-bioreactor system for a tissue-engineered trachea. Biomaterials 2009; 30: 4117-4126.

Okumuş A, Çizmeci O, Kabakas F, et al. Circumferential trachea reconstruction with a prefabricated axial bio-synthetic flap: experimental study. Int J Pediatr Otorhinolaryngol 2005; 69: 335-344.

Machino R, Matsumoto K, Taniguchi D, et al. Replacement of rat tracheas by layered, trachea-like, scaffold-free structures of human cells using a bio-3D printing system. Adv Healthc Mater 2019; 8: e1800983.

Park JH, Park JY, Nam I-C, et al. A rational tissue engineering strategy based on three-dimensional (3D) printing for extensive circumferential tracheal reconstruction. Biomaterials 2018; 185: 276-283.

Bae SW, Lee KW, Park JH, et al. 3D bioprinted artificial trachea with epithelial cells and chondrogenic-differentiated bone marrow-derived mesenchymal stem cells. Int J Mol Sci 2018; 19: 1624.

Kaye R, Goldstein T, Grande DA, et al. A 3-dimensional bioprinted tracheal segment implant pilot study: Rabbit tracheal resection with graft implantation. Int J Pediatr Otorhinolaryngol 2019; 117: 175-178.

Gao B, Jing H, Gao M, et al. Long-segmental tracheal reconstruction in rabbits with pedicled tissue-engineered trachea based on a 3D-printed scaffold. Acta Biomater 2019; 97: 177-186.

Park HS, Park HJ, Lee J, et al. A 4-axis technique for three-dimensional printing of an artificial trachea. Tissue Eng Regen Med 2018; 15: 415-425.

Zang M, Zhang Q, Davis G, et al. Perichondrium directed cartilage formation in silk fibroin and chitosan blend scaffolds for tracheal transplantation. Acta Biomater 2011; 7: 3422-3431.

Gobin AS, Butler CE, Mathur AB. Repair and regeneration of the abdominal wall musculofascial defect using silk fibroin-chitosan blend. Tissue Eng 2006; 12: 3383-3394.

Altman AM, Yan Y, Matthias N, et al. IFATS collection: Human adipose-derived stem cells seeded on a silk fibroin-chitosan scaffold enhance wound repair in a murine soft tissue injury model. Stem Cells 2009; 27: 250-258.

Ríos CN, Skoracki RJ, Miller MJ, et al. In vivo bone formation in silk fibroin and chitosan blend scaffolds via ectopically grafted periosteum as a cell source: a pilot study. Tissue Eng A 2009; 15: 2717-2725.

Deslauriers J, Aubrée N, Shamji FM. Experiences with prosthetic airway replacement. Thorac Surg Clin 2018; 28: 377-384.

Les AS, Ohye RG, Filbrun AG, et al. 3D-printed, externally-implanted, bioresorbable airway splints for severe tracheobronchomalacia. Laryngoscope 2019; 129: 1763-1771.

Morrison RJ, Hollister SJ, Niedner MF, et al. Mitigation of tracheobronchomalacia with 3D-printed personalized medical devices in pediatric patients. Sci Transl Med 2015; 7: $285 \mathrm{ra64}$. Gopinathan J, Noh I. Recent trends in bioinks for 3D printing. Biomater Res 2018; 22 : 11.

Xia D, Jin D, Wang Q, Gao M, Zhang J, Zhang H, et al. Tissue-engineered trachea from a 3D-printed scaffold enhances whole-segment tracheal repair in a goat model. J Tissue Eng Regen Med 2019; 13: 694-703.

Hsieh C-T, Liao C-Y, Dai N-T, et al. 3D printing of tubular scaffolds with elasticity and complex structure from multiple waterborne polyurethanes for tracheal tissue engineering. Appl Materials Today 2018; 12: 330-341. 
Sears NA, Seshadri DR, Dhavalikar PS, et al. A review of three-dimensional printing in tissue engineering. Tissue Eng B Rev 2016; 22: 298-310.

Atala A, Forgacs G. Three-dimensional bioprinting in regenerative medicine: reality, hype, and future. Stem Cells Transl Med 2019; 8: 744-745.

Graziano JL, Spinazzola A, Neville WE. Prosthetic replacement of the tracheal carina. Ann Thorac Surg 1967; 4: $1-11$.

Neville WE, Bolanowski JP, Kotia GG. Clinical experience with the silicone tracheal prosthesis. J Thorac Cardiovasc Surg 1990; 99: 604-612.

Etienne H, Fabre D, Gomez Caro A, et al. Tracheal replacement. Eur Respir J 2018; 51: 1702211.

Beall AC, Harrington OB, Greenberg SD, et al. Tracheal replacement with heavy Marlex mesh. Circumferential replacement of the cervical trachea. Arch Surg 1962; 84: 390-396.

elsey R. Stainless steel wire suture technique in thoracic surgery. Thorax 1946; 1: 39-47. case. Arch Surg 1948; 57: 253-266.

Longmire WP, Jr. The repair of large defects of the trachea. Ann Otol Rhinol Laryngol 1948; 57: 875-883.

Maziak DE, Todd TR, Keshavjee SH, et al. Adenoid cystic carcinoma of the airway: thirty-two-year experience. J Thorac Cardiovasc Surg 1996; 112: 1522-1531.

Gebauer PW. Experiences with surgical reconstruction of the trachea. Am Rev Tuberc 1950; 62: 176-189.

Bucher RM, Burnett WE, Rosemond GP. Experimental reconstruction of tracheal and bronchial defects with stainless steel wire mesh. J Thorac Surg 1951; 21: 572-583.

Pearson FG, Henderson RD, Gross AE, et al. The reconstruction of circumferential tracheal defects with a porous prosthesis. An experimental and clinical study using heavy Marlex mesh. J Thorac Cardiovasc Surg 1968; 55: 605-616.

Montgomery WW. Silicone tracheal T-tube. Ann Otol Rhinol Laryngol 1974; 83: 71-75.

Husain SA, Finch D, Ahmed M, et al. Long-term follow-up of ultraflex metallic stents in benign and malignant central airway obstruction. Ann Thorac Surg 2007; 83: 1251-1256.

Shepherd RW, Lamb C, Beamis JF. Clinical experience of the Polyflex ${ }^{\mathrm{TM}}$ stent in benign and malignant central airway obstruction. Chest 2006; 130: 110S.

Folch E, Keyes C. Airway stents. Ann Cardiothorac Surg 2018; 7: 273-283.

Terra RM, Minamoto H, Tedde ML, et al. Self-expanding stent made of polyester mesh with silicon coating (Polyflex) in the treatment of inoperable tracheal stenoses. J Bras Pneumol 2007; 33: 241-247.

Guibert N, Saka H, Dutau H. Airway stenting: Technological advancements and its role in interventional pulmonology. Respirology 2020; 25: 953-962.

Dutau H, Toutblanc B, Lamb C, et al. Use of the Dumon Y-stent in the management of malignant disease involving the carina. Chest 2004; 126: 951-958.

Freitag L, Tekolf E, Stamatis C. Clinical evaluation of a new bifurcated dynamic airway stent: a 5-year experience with 135 patients. Throac Cardiovasc Surg 1997; 45: 6-12.

Seguin A, Radu D, Holder-Espinasse M, et al. Tracheal replacement with cryopreserved, decellularized, or glutaraldehyde-treated aortic allografts. Ann Thorac Surg 2009; 87: 861-867.

8 Tsukada H, Ernst A, Gangadharan S, et al. Tracheal replacement with a silicone-stented, fresh aortic allograft in sheep. Ann Thorac Surg 2010; 89: 253-258.

Wurtz A, Hysi I. Tracheal replacement with aortic allografts in humans. Experimental prospects. Rev Mal Respir 2012; 29: 941-944.

0 Azorin JF, Bertin F, Martinod E, et al. Tracheal replacement with an aortic autograft. Eur J Cardiothorac Surg 2006; 29: 261-263.

Martinod E, Radu DM, Chouahnia K, et al. Human transplantation of a biologic airway substitute in conservative lung cancer surgery. Ann Thorac Surg 2011; 91: 837-842.

2 Wurtz $\mathrm{A}$, Porte $\mathrm{H}$, Conti M, et al. Surgical technique and results of tracheal and carinal replacement with aortic allografts for salivary gland-type carcinoma. J Thorac Cardiovasc Surg 2010; 140: 387-93.e2.

Martinod E, Chouahnia K, Radu DM, et al. Feasibility of bioengineered tracheal and bronchial reconstruction using stented aortic matrices. JAMA 2018; 319: 2212-2222.

Rose KG, Sesterhenn K, Wustrow F. Tracheal allotransplantation in man. Lancet 1979; 1: 433.

Levashov Yu N, Yablonsky PK, Cherny SM, et al. One-stage allotransplantation of thoracic segment of the trachea in a patient with idiopathic fibrosing mediastinitis and marked tracheal stenosis. Eur J Cardiothorac Surg 1993; 7: 383-386.

6 Delaere PR, Vranckx JJ, Den Hondt M. Tracheal allograft after withdrawal of immunosuppressive therapy. N Engl J Med 2014; 370: 1568-1570.

7 Delaere $\mathrm{P}$, Vranckx J, Verleden $\mathrm{G}$, et al. Tracheal allotransplantation after withdrawal of immunosuppressive therapy. N Engl J Med 2010; 362: 138-145.

Delaere PR, Vranckx JJ, Meulemans J, et al. Learning curve in tracheal allotransplantation. Am J Transplant 2012; 12: 2538-2545. 
129 Fabre D, Kolb F, Fadel E, et al. Successful tracheal replacement in humans using autologous tissues: an 8-year experience. Ann Thorac Surg 2013; 96: 1146-1155.

130 Mercier O, Kolb F, Dartevelle PG. Autologous tracheal replacement: surgical technique and outcomes. Thorac Surg Clin 2018; 28: 347-355.

131 Beldholm BR, Wilson MK, Gallagher RM, et al. Reconstruction of the trachea with a tubed radial forearm free flap. J Thorac Cardiovasc Surg 2003; 126: 545-550.

132 Yu P, Clayman GL, Walsh GL. Human tracheal reconstruction with a composite radial forearm free flap and prosthesis. Ann Thorac Surg 2006; 81: 714-716.

133 Fabre D, Fadel E, Mussot S, et al. Autologous tracheal replacement for cancer. Chin Clin Oncol 2015; 4: 46.

134 Steinke M, Dally I, Friedel G, et al. Host-integration of a tissue-engineered airway patch: two-year follow-up in a single patient. Tissue Eng Part A 2015; 21: 573-579.

135 Elliott MJ, De Coppi P, Speggiorin S, et al. Stem-cell-based, tissue engineered tracheal replacement in a child: a 2-year follow-up study. Lancet 2012; 380: 994-1000.

136 Hamilton NJ, Kanani M, Roebuck DJ, et al. Tissue-engineered tracheal replacement in a child: a 4-year follow-up study. Am J Transplant 2015; 15: 2750-2757.

137 Elliott MJ, Butler CR, Varanou-Jenkins A, et al. Tracheal replacement therapy with a stem cell-seeded graft: lessons from compassionate use application of a GMP-compliant tissue-engineered medicine. Stem Cells Transl Med 2017; 6: 1458-1464.

138 Omori K, Nakamura T, Kanemaru S, et al. Regenerative medicine of the trachea: the first human case. Ann Otol Rhinol Laryngol 2005; 114: 429-433.

139 Omori K, Tada Y, Suzuki T, et al. Clinical application of in situ tissue engineering using a scaffolding technique for reconstruction of the larynx and trachea. Ann Otol Rhinol Laryngol 2008; 117: 673-678.

140 Kanemaru S, Hirano S, Umeda $\mathrm{H}$, et al. A tissue-engineering approach for stenosis of the trachea and/or cricoid. Acta Otolaryngol Suppl 2010; 563: 79-83.

141 Zopf DA, Hollister SJ, Nelson ME, et al. Bioresorbable airway splint created with a three-dimensional printer. N Engl J Med 2013; 368: 2043-2045.

142 Huang L, Wang L, He J, et al. Tracheal suspension by using 3-dimensional printed personalized scaffold in a patient with tracheomalacia. J Thorac Dis 2016; 8: 3323-3328.

143 Morrison RJ, Sengupta S, Flanangan CL, et al. Treatment of severe acquired tracheomalacia with a patient-specific, 3D-printed, permanent tracheal splint. JAMA Otolaryngol Head Neck Surg 2017; 143: 523-525.

144 Cleveland Clinic. FDA Approves 3D-printed Airway Stents Developed by Cleveland Clinic Doctor [press release]. 8 January 2020. https://newsroom.clevelandclinic.org/2020/01/08/fda-approves-3d-printed-airwaystents-developed-by-cleveland-clinic-doctor/

145 Guibert N, Didier A, Moreno B, et al. Treatment of post-transplant complex airway stenosis with a three-dimensional, computer-assisted customized airway stent. Am J Respir Crit Care Med 2017; 195: e31-e33.

146 Shieh HF, Jennings RW. Three-dimensional printing of external airway splints for tracheomalacia. $J$ Thorac Dis 2017; 9: 414-416.

147 Eskandari M, Arvayo AL, Levenston ME. Mechanical properties of the airway tree: heterogeneous and anisotropic pseudoelastic and viscoelastic tissue responses. J Appl Physiol 2018; 125: 878-888.

148 Bilston LE, Gandevia SC. Biomechanical properties of the human upper airway and their effect on its behavior during breathing and in obstructive sleep apnea. J Appl Physiol 2014; 116: 314-324.

149 Knaneh-Monem H, Thornton ME, Grubbs BH, et al. Differential epithelial growth in tissue-engineered larynx and trachea generated from postnatal and fetal progenitor cells. Biochem Biophys Res Commun 2019; 510: 205-210. 